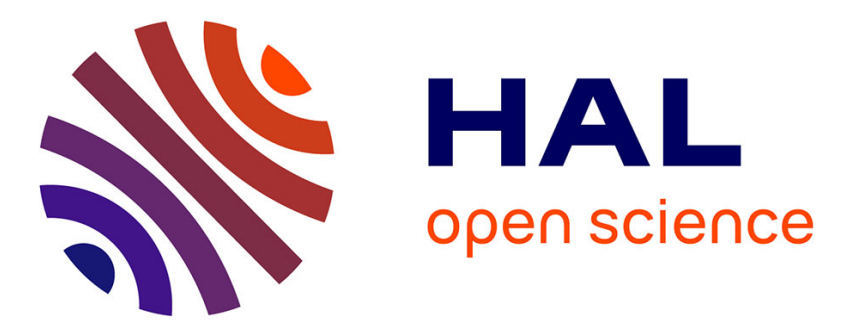

\title{
Anti-apoptotic Bcl-2 fails to form efficient complexes with pro-apoptotic Bak to protect from Celecoxib-induced apoptosis
}

Justine Rudner, Simon J. Elsaesser, Verena Jendrossek, Stephan M. Huber

\section{- To cite this version:}

Justine Rudner, Simon J. Elsaesser, Verena Jendrossek, Stephan M. Huber. Anti-apoptotic Bcl-2 fails to form efficient complexes with pro-apoptotic Bak to protect from Celecoxib-induced apoptosis. Biochemical Pharmacology, 2010, 81 (1), pp.32. 10.1016/j.bcp.2010.09.002 . hal-00642423

HAL Id: hal-00642423

https://hal.science/hal-00642423

Submitted on 18 Nov 2011

HAL is a multi-disciplinary open access archive for the deposit and dissemination of scientific research documents, whether they are published or not. The documents may come from teaching and research institutions in France or abroad, or from public or private research centers.
L'archive ouverte pluridisciplinaire HAL, est destinée au dépôt et à la diffusion de documents scientifiques de niveau recherche, publiés ou non, émanant des établissements d'enseignement et de recherche français ou étrangers, des laboratoires publics ou privés. 


\section{Accepted Manuscript}

Title: Anti-apoptotic Bcl-2 fails to form efficient complexes with pro-apoptotic Bak to protect from Celecoxib-induced apoptosis

Authors: Justine Rudner, Simon J. Elsaesser, Verena Jendrossek, Stephan M. Huber

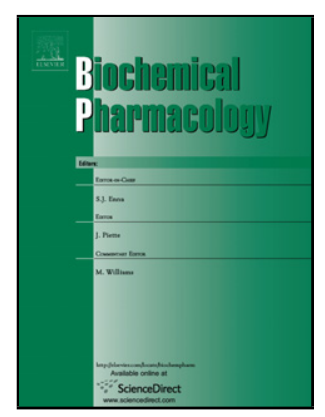

PII: S0006-2952(10)00658-1

DOI: doi:10.1016/j.bcp.2010.09.002

Reference: BCP 10707

To appear in: $\quad B C P$

Received date: $\quad 9-7-2010$

Revised date: $\quad 31-8-2010$

Accepted date: $\quad$ 2-9-2010

Please cite this article as: Rudner J, Elsaesser SJ, Jendrossek V, Huber SM, Anti-apoptotic Bcl-2 fails to form efficient complexes with pro-apoptotic Bak to protect from Celecoxib-induced apoptosis, Biochemical Pharmacology (2010), doi:10.1016/j.bcp.2010.09.002

This is a PDF file of an unedited manuscript that has been accepted for publication. As a service to our customers we are providing this early version of the manuscript. The manuscript will undergo copyediting, typesetting, and review of the resulting proof before it is published in its final form. Please note that during the production process errors may be discovered which could affect the content, and all legal disclaimers that apply to the journal pertain. 


\section{Anti-apoptotic Bcl-2 fails to form efficient complexes with pro-apoptotic}

\section{Bak to protect from Celecoxib-induced apoptosis}

Justine Rudner ${ }^{1}$, Simon J. Elsaesser ${ }^{1,3}$, Verena Jendrossek ${ }^{2}$, Stephan M. Huber ${ }^{1}$

${ }^{1}$ Department of Radiation Oncology, University Hospital of Tübingen, Hoppe-Seyler-Str. 3, 72076 Tübingen, Germany

${ }^{2}$ Institute for Cell Biology, Department of Molecular Cell Biology, University of DuisburgEssen, Virchowstrasse 173, 45122 Essen, Germany

${ }^{3}$ present address: Rockefeller University, 1230 York Ave, New York, NY 10065

\section{Corresponding author:}

Justine Rudner, University of Tübingen, Department of Radiation Oncology, Hoppe-SeylerStr. 3, 72076 Tübingen, Germany

E-mail: justine.rudner@med.uni-tuebingen.de, Phone: +49-7071-2982183; Fax: +49-7071294944

Manuscript Category: Antibiotics and Chemotherapeutics

Short title: Lack of Bcl-2 protection during Celecoxib-induced apoptosis

\section{Key words:}

Intrinsic apoptosis, Celecoxib, Bcl-2, Bcl-xL, Mcl-1, Bak

Word count abstract: 169

Word count text: 4997

Number of figures: 7

Number of tables: 0

Number of references: 51 


\section{Abstract:}

The non-steroidal anti-inflammatory drug Celecoxib is a specific inhibitor of cyclooxygenase-

2. Apart from its inhibitor function, Celecoxib induces apoptosis through the intrinsic pathway which is controlled by the Bcl-2 family members. In Jurkat T lymphoma cells, treatment with Celecoxib results in a rapid decline of the anti-apoptotic Bcl-2-related protein Mcl-1. The depletion of Mcl-1 was sufficient for apoptosis induction and could be blocked by overexpression of Bcl-xL but not the close homologue Bcl-2. The present investigation analyzed the mechanism by which Bcl-xL prevents apoptosis induction whereas Bcl-2 failed to. Our data show that the involvement of the orphan nuclear receptor Nur77/TR3 specifically targeting Bcl-2 but not Bcl-xL was not involved in Celecoxib-induced apoptosis. Surprisingly, BH3-only proteins Bid, Bim, and Puma of the Bcl-2 family were not needed either. However, unlike Bcl-2, Mcl-1, and Bcl-xL sequestered Bak preventing it from activation through a direct interaction. Thus, when abundantly expressed, Bcl-xL can substitute for the loss of Mcl-1 whereas Bcl-2, incapable of forming a high affinity complex with Bak, could not. 


\section{Introduction:}

The non-steroidal anti-inflammatory drug Celecoxib (Cerebrex $®)$ is a specific inhibitor of cyclooxygenase-2 (COX-2) with anti-neoplastic properties [1]. COX-2 is involved in prostaglandin production during the inflammatory response [2]. The enzyme is also overexpressed in many human tumors and contributes to tumorigenesis [3]. Thus, in addition to their anti-inflammatory activities, coxibes might interfere with tumor progression $[4,5]$. Previous experiments in COX-2-negative cell lines and with Celecoxib derivates lacking the COX-2 inhibitory function indicate that Celecoxib might have yet other targets through which it exerts cytotoxic effects [6-10]. We have recently shown that Celecoxib induced apoptosis through the intrinsic pathway [11-13]. This apoptotic pathway involves permeabilization of the outer mitochondrial membrane and the dissipation of mitochondrial membrane potential $[14,15]$. Apoptogenic factors which are found in the mitochondrial intermembrane space of healthy cells are released into the cytosol where they facilitate the activation of caspases, the executers of the apoptotic death program.

Members of the Bcl-2 protein family are the gate keepers of the mitochondrial homeostasis regulating the release of pro-apoptotic factor from the mitochondrial intermembrane space into the cytosol. The Bcl-2 protein family consists of pro- and anti-apoptotic members which are able to form heterodimers $[16,17]$. Among others, the anti-apoptotic group encompasses Bcl-2, Bcl-xL, Mcl-1, and A1 which are often found to be over-expressed in tumor tissues. The pro-apoptotic group is divided in multi-domain proteins (Bax, Bak, Bok) which share three Bcl-2 homologous domains (BH1-3) and the BH3-only proteins (Bim, Bid, Puma, Bad, Bik, Bmf, Noxa) which have only the BH3 domain in common.

The activation of the multi-domain proteins is absolutely essential for mitochondrial permeabilization and apoptosis induction. Currently, two theories exist which explain the involvement of the different anti-apoptotic and $\mathrm{BH} 3$-only proteins leading to activation of 
Bak/Bax-like proteins. In the displacement model, the multidomain proteins are neutralized by the anti-apoptotic Bcl-2 family members in healthy cells [16, 18]. Upon apoptosis induction, $\mathrm{BH} 3$-only proteins bind to the anti-apoptotic ones thereby displacing Bax or Bak allowing them to be activated through spontaneous self-oligomerization.

The direct activation or hierarchical model discernes BH3-only protein activators (Bim, Bid, and sometimes Puma) and sensitizers (Bad, Bik, Bmf, Noxa) [19, 20]. The former bind to all anti-apoptotic proteins with similar affinity as well as to the pro-apoptotic multidomain proteins whereas the latter do not interact with Bax/Bak-like proteins. Moreover, sensitizer BH3-only proteins display distinct binding preferences to the anti-apoptotic ones. So associated Noxa with Mcl-1 and A1 only while Bad interacts with Bcl-2 and Bcl-xL. In healthy cells, the activators are sequestered by the anti-apoptotic proteins. A certain apoptotic stimulus activates distinct set of sensitizer proteins which, in turn, bind their preferred antiapoptotic partners. The activator proteins, when released from their sequestration, bind to the Bax/Bak-like proteins to induce their oligomerization.

Our previous investigations have shown that Celecoxib induced apoptosis through the Noxa/Mcl-1 axis in Jurkat T cell lymphoma cells leading to downregulation of Mcl-1 [7]. The depletion of Mcl-1 protein levels was sufficient to induce apoptosis in this cell system. Interestingly, overexpression of Bcl-xL but not Bcl-2 could prevent induction of apoptosis in response to Celecoxib [7, 11]. The mechanisms which lead to specific neutralization of Bcl-2 remain elusive. Because of their high sequence homology, Bcl-2 and Bcl-xL were thought to fulfill a redundant protective function. Their binding affinities to other $\mathrm{BH} 3$-only proteins are similar but they might also interact with specific partner [21, 22].

In this present investigation, we examined the mechanism leading to neutralization of Bcl-2 but not the closely related Bcl-xL during Celecoxib-induced apoptosis in Jurkat T cells. Downregulation of activator BH3-only proteins Bim and Puma by siRNA revealed that their presence is not essential for mitochondrial permeabilization and apoptosis induction by 
Celecoxib. Nor was the activator BH3-only protein Bid which was converted into the apoptotic truncated Bid (tBid) by caspases downstream of $\Delta \Psi \mathrm{m}$ dissipation. We also excluded the involvement of Nur77/TR3 which targets Bcl-2 but not Bcl-xL to transfer it from an anti-apoptotic molecule into a pro-apoptotic one. However, we found a strong interaction of Mcl-1 and Bcl-xL with Bak in healthy Jurkat Vector control and Bcl-xLoverexpressing cells. A Bcl-2:Bak interaction was observed only when Bcl-2 was overexpressed. When harsher lysis conditions were applied the complex of Bcl-2 and Bak could not be detected any longer while Bcl-xL and Mcl-1 still associated with Bak. The present data clearly show that Bcl-2 cannot replace Bcl-xL in Jurkat T cells during Celecoxibinduced apoptosis.

We concluded that Bcl-xL and Mcl-1 prevented activation of Bak through direct interaction. When sufficiently expressed, Bcl-xL can substitute for Mcl-1 loss in response to Celecoxib. Bcl-2, however, which is not able to form high affinity complexes with Bak, fails to inhibit Bak activation after Mcl-1 downregulation. 


\section{Material and methods:}

\subsection{Reagents and antibodies}

All chemicals were purchased from Sigma-Aldrich (Deisenhofen, Germany) unless otherwise specified. The pan-caspase inhibitor zVAD-fmk was purchased from Bachem (Weil/Rhein, Germany). Celecoxib was kindly provided by Pharmacia-Pfizer (Erlangen, Germany). Following antibodies were used for Western blotting and immunoprecipitation: mouse-anti caspase-9 and rabbit-anti Bak NT from Upstate (Millipore, Schwalbach, Germany), rabbitanti caspase-3, PARP, Mcl-1, Bcl-xL, Bid, Nur77, and Tubulin from Cell Signaling (NEB Frankfurt, Germany), mouse-anti caspase-8 from BioCheck (Münster, Germany), rabbit-anti Puma and Bim from Epitomics (Biomol, Hamburg, Germany), mouse- and rabbit-anti Bcl-2 from Santa Cruz Biotechnology (Heidelberg, Germany), mouse-anti Mcl-1 from Pharmingen (Becton Dickinson, Heidelberg, Germany), mouse-anti Bcl-xL from Transduction Lab (Becton Dickinson, Heidelberg, Germany), mouse-anti Bak (clone TC-100) from Calbiochem (Merck, Darmstadt, Germany), mouse-anti GAPDH from Abcam (Cambridge, UK), and mouse-anti $\beta$-Actin was obtained from Sigma (Deisenhofen, Germany).

\subsection{Cells and cell culture}

Jurkat E6.1 T-lymphoma cells were from ATCC (Bethesda, Maryland, USA). Jurkat cells stably expressing $\mathrm{Bcl}-\mathrm{xL}$ or Bcl-2 and the respective Vector control were prepared as described before [7]. Cells were grown in RPMI 1640 medium supplemented with $10 \%$ fetal calf serum (Gibco Life Technologies, Eggenstein, Germany) and maintained in a humidified incubator at $37^{\circ} \mathrm{C}$ and $5 \% \mathrm{CO}_{2}$. 


\subsection{Transfection with siRNA}

Cells were cultured at a low density to ensure log phase growth. For transfection $2 \times 10^{6}$ cells were resuspended in $200 \mu \mathrm{L}$ RPMI-1640 without phenol red. Shortly before transfection, bim, puma, or non-targeting siRNA was added at indicated concentration. bim and puma ONTARGET SMARTpool and the siCONTROL NON-TARGETING pool siRNA was purchased from Dharmacon (Chicago, IL, USA). Cells were electroporated in a $4 \mathrm{~mm}$ cuvette in an EPI2500 electroporator (Fischer, Heidelberg, Germany) at $370 \mathrm{~V}$ for $10 \mathrm{msec}$. Immediately after transfection cells were resuspended in $6 \mathrm{~mL}$ pre-warmed medium and continued to be cultured as described above. Transfection efficiency and viability was determined by transfecting the cells with $400 \mathrm{nM}$ green fluorescence siRNA (siGLO from Dharmacon, Chicago, IL, USA) followed by propidium iodide exclusion dye and flow cytometric analysis.

\subsection{Flow cytometric analysis}

The mitochondrial membrane potential $(\Delta \Psi \mathrm{m})$ was analyzed using the $\Delta \Psi \mathrm{m}$ specific dye TMRE (Molecular Probes, Mobitech, Göttingen, Germany). At the indicated time points $10^{5}$ cells were stained for 30 min in PBS containing $25 \mathrm{nM}$ TMRE. Co-incubation with $1 \mu \mathrm{M}$ of the cyanide derivate CCCP was used as a positive control to complete the mitochondrial depolarisation. Apoptosis induction was analyzed by Annexin V-PI double staining. In brief, $10^{5}$ cells were incubated in a solution containing $10 \mathrm{mM}$ HEPES, $\mathrm{pH}$ 7.4, $140 \mathrm{mM} \mathrm{NaCl}, 2.5$ $\mathrm{mM} \mathrm{CaCl}_{2}, 1: 50$ diluted Annexin-V-FLUOS (Roche Diagnostics, Mannheim, Germany), and $10 \mu \mathrm{g} / \mathrm{mL}$ propidium iodide. Cells stained with TMRE were detected in channel 2 , cells stained with Annexin V-PI in channel 1 and 3 employing a FACS Calibur flow cytometer and the Cell Quest software from Becton Dickinson (Heidelberg, Germany). Flow cytometric analysis was performed using the FCS Express software (De Novo Software, Los Angeles, CA, USA). Data show mean values +/- S.D. of at least 3 independent experiments. 


\subsection{Western blot analysis}

Cells were lysed in $200 \mu \mathrm{L}$ lysis buffer containing $50 \mathrm{mM}$ HEPES $\mathrm{pH} 7.5,150 \mathrm{mM} \mathrm{NaCl}, 1 \%$ Triton X-100, 1 mM EDTA, $10 \mathrm{mM}$ sodium pyrophosphate, $10 \mathrm{mM} \mathrm{NaF}, 2 \mathrm{mM} \mathrm{Na} \mathrm{VO}_{4}, 100$ mM PMSF, $5 \mu \mathrm{g} / \mathrm{mL}$ Aprotinin, $5 \mu \mathrm{g} / \mathrm{mL}$ Leupeptin, and $3 \mu \mathrm{g} / \mathrm{mL}$ Pepstatin. After removing insoluble material by centrifugation for $10 \mathrm{~min}$ at $18000 \mathrm{x}$ g, the protein concentration was estimated in the supernatant using the Bio-Rad protein assay (Bio-Rad, Munich, Germany) according to the manufacturer's protocol. Protein was separated by SDS-PAGE under reducing conditions before transfer onto PVDF membranes (Roth, Karlsruhe, Germany). Blots were blocked in TBS buffer containing $0.05 \%$ Tween-20 and 5\% non-fat dry milk for 1 $\mathrm{h}$ at room temperature. The membrane was incubated overnight at $4^{\circ} \mathrm{C}$ with the respective primary antibodies. After repeated washings with TBS/Tween-20 $(0.05 \%)$ the membranes were incubated with the secondary antibody for $1 \mathrm{~h}$ at room temperature before continuing to wash with TBS/Tween-20 (0,05\%). Detection of antibody binding was performed by enhanced chemoluminescence (ECL Western blotting analysis system, GE Healthcare/Amersham-Biosciences, Freiburg, Germany). Equal loading was verified by antibodies against Tubulin, GAPDH, or $\beta$-Actin. All Western blot experiments were repeated at least once.

\subsection{Immunoprecipitation}

Cells were lysed as described above using either $1 \%$ CHAPS or $1 \%$ Triton X-100. The protein concentration was adjusted to $2 \mathrm{mg} / \mathrm{mL}$. $5 \mu \mathrm{g}$ antibody and $50 \mu \mathrm{L}$ slurry Dynabeads ${ }^{\circledR}$ suspension (Dynal/Invitrogen, Karlsruhe, Germany) were added to $750 \mu \mathrm{L}$ lysate. After the precipitation for $3 \mathrm{~h}$ at $4{ }^{\circ} \mathrm{C}$ the beads were washed thrice with $300 \mu \mathrm{L}$ lysis buffer containing $0.2 \%$ of the respective detergent. Proteins were eluted by boiling the beads for $5 \mathrm{~min}$ in 100 $\mu \mathrm{L}$ SDS sample buffer with $\beta$-Mercaptoethanol. $30 \mu \mathrm{L}$ were separated by SDS gel 


\subsection{Data analysis}

ED50 values for cells with low $\Delta \Psi \mathrm{m}$ were calculated after fitting the flow cytometric results according to the equation $\mathrm{y}=\left(\mathrm{A}_{1}-\mathrm{A}_{2}\right) /\left(1+\mathrm{e}^{(\mathrm{x}-\mathrm{x} 0) / \mathrm{dx}}\right)+\mathrm{A} 2$, ED50 values for healthy AnnV/PI double negative cells according to the equation $y=100-\left[\left(A_{1}-A_{2}\right) /\left(1+e^{(x-x 0) / d x}\right)+A 2\right]$. Statistical significance between the ED50 values for different cell lines was calculated by ANOVA test using GraphPad Software (San Diego, CA, USA, www.graphpad.com). 


\section{Results:}

\subsection{Apoptosis induction by Celecoxib in Jurkat T cells overexpressing Bcl-2 and Bcl-xL}

First, we examined apoptosis induction in Jurkat Vector cells and in Jurkat cells overexpressing Bcl-2 or Bcl-xL. Celecoxib triggered apoptosis in Jurkat Vector cells in a concentration-dependent manner. 6h after treatment with Celecoxib the amount of Annexin V-positive cells was dramatically elevated (Fig. 1A). $50 \mu \mathrm{M}$ Celecoxib were sufficient to induce apoptosis in $30 \%$ of the cells. The dissipation of mitochondrial membrane potential $(\Delta \Psi \mathrm{m})$ coincided with apoptosis induction (Fig. 1B). Bcl-2-overexpressing cells were similar sensitive to Celecoxib-induced apoptosis and $\Delta \Psi \mathrm{m}$ dissipation while overexpression of Bcl$\mathrm{xL}$ was strongly protective (Fig. 1A and 1B). The calculated ED50 values for Celecoxibinduced apoptosis (healthy, AnnV/PI double negative cells) and $\Delta \Psi \mathrm{m}$ dissipation $(\Delta \Psi \mathrm{m}$ low) in Vector $(\mathrm{ED} 50(\mathrm{AnnV}-/ \mathrm{PI}-)=63.5+/-2.2 \mu \mathrm{M})$, ED50 $(\Delta \Psi \mathrm{m}$ low $)=61.4+/-2.3 \mu \mathrm{M})$ and Bcl2-overexpressing cells (ED50(AnnV-/PI- $)=71.4+/-2.2 \mu \mathrm{M}, \mathrm{ED} 50(\Delta \Psi \mathrm{m}$ low $)=67.6+/-0.2$ $\mu \mathrm{M})$ were very similar (Fig. 1C and FigS1). In constrast, significantly higher concentrations were calculated for Bcl-xL-overexpressing cells (ED50(AnnV-/PI-) $=166.4+/-11.3 \mu \mathrm{M}$, $\operatorname{ED50}(\Delta \Psi \mathrm{m}$ low $)=132.1+/-11.4 \mu \mathrm{M})$. Caspase activation, a hallmark of apoptosis induction downstream of $\Delta \Psi \mathrm{m}$ dissipation, could be detected in Jurkat Vector and Jurkat Bcl-2 cells as early as $3 \mathrm{~h}$ after treatment with $75 \mu \mathrm{M}$ Celecoxib (Fig. 1D). The initiator caspase-9, executing caspase-3, the caspase- 3 substrates PARP, and caspase- 8 were fully active $6 \mathrm{~h}$ after administration of Celecoxib in those cells, while no cleavage fragments were observed in cells overexpression of Bcl-xL.

The downregulation of Mcl-1 is essential for Celecoxib-induced apoptosis [7]. We observed a drastic reduction of Mcl-1 protein levels as early as $3 \mathrm{~h}$ after treatment with $75 \mu \mathrm{M}$ Celecoxib whereas levels of Bcl-2, Bcl-xL, and Bak remained unchanged (Fig. 1D). The decline of Mcl- 
1 shows a similar profile in Jurkat Vector cells and in Bcl-2- and Bcl-xL-overexpressing cells does not correlate with caspase activation suggesting that Mcl-1 protein level is not regulated by caspases. Indeed, treatment with $30 \mu \mathrm{M}$ of the pan-caspase inhibitor $\mathrm{zVAD}$ did not prevent the initial decline of Mcl-1 protein levels $3 \mathrm{~h}$ after treatment with Celecoxib but attenuated the total removal during the executive phase of apoptosis (Fig. 2C).

\subsection{Role of activator BH3-only proteins during Celecoxib-induced apoptosis}

So far, the results from this experiments confirm previous observations demonstrating the early downregulation of Mcl-1 during Celecoxib-induced apoptosis, the protection by Bcl-xL overexpression and the lack thereof by Bcl-2 overexpression $[7,12]$. To explore the mechanism of Celecoxib-induced apoptosis further, BH3-only proteins of the Bcl-2 family and their preferred interaction partners were analyzed. The focus was on the activator $\mathrm{BH} 3-$ only proteins which include Bid, Bim and sometimes Puma because a direct interaction of activator BH3-only proteins with Bax/Bak is thought to be prerequisite for activation of the multi-domain proteins. According to the sequestration model the binding preferences of Bcl-2 and $\mathrm{Bcl}-\mathrm{xL}$ to different $\mathrm{BH} 3$-only proteins might change during Celecoxib-induced apoptosis. Thus, the expression levels of the three BH3-only proteins were examined (Fig. 2A). Bim is expressed as an extra large, a large, or a small splice variant $\left(\mathrm{Bim}_{\mathrm{EL}}, \mathrm{Bim}_{\mathrm{L}}\right.$, and $\mathrm{Bim}_{\mathrm{S}}$ respectively). Puma is expressed as Puma- $\alpha$ and Puma $\beta$ whereas Bid is expressed in an inactive p22 pro-form in healthy Jurkat cells which needs to be processed into a p15 fragment to be activated during apoptosis (Fig. 2A).

The protein levels of Bim remained unchanged during Celecoxib-induced apoptosis, but a strong reduction of pro-apoptotic Puma levels and cleavage of Bid were observed in Jurkat Vector and Jurkat Bcl-2 cells (Fig. 2A). Since both of the events correlated with caspase activation, we tested whether the pan-caspase inhibitor zVAD could abrogate Bid cleavage and Puma decline. Treatment with zVAD blocked Celecoxib-induced exposure of Annexin V 
while $\Delta \Psi \mathrm{m}$ dissipation was unaffected (Fig. 2B upper and lower panel, respectively).

Furthermore, zVAD interfered with caspase- 9 , caspase-3, and caspase-8 activation as well as PARP and Bid cleavage and inhibited Puma decline (Fig. 2C). The results indicate that the regulation of Bid and Puma occurs in the executive phase of apoptosis upon caspase activation and plays a minor role before $\Delta \Psi \mathrm{m}$ dissipation.

Full length Bid (p23) has to be processed to a p15 fragment to fully display its pro-apoptotic potential. In contrast, Puma can change its interaction partners before its degradation. To analyze its relevance for Celecoxib-induced apoptosis in Jurkat cells, Puma was downregulated by siRNA. Puma levels were reduced about $50 \% 72 \mathrm{~h}$ after electroporation with $1 \mu \mathrm{M}$ siRNA into Jurkat cells (Fig. 3A). So, 72h after electroporation of $1 \mu \mathrm{M}$ puma siRNA or the non-targeting control siRNA, the cells were treated with 50-100 $\mu \mathrm{M}$ Celecoxib for 6h. Apoptosis induction (Fig. 3B) and $\Delta \Psi \mathrm{m}$ dissipation (Fig. 3C) occurred with similar effectivity in cells transfected with non-targeting or puma siRNA. In addition, Puma could be co-precipitated neither with Mcl-1 nor Bcl-2, Bcl-xL, or Bak (Fig. 3D) indicating that this BH3-only protein plays no role during Celecoxib-induced apoptosis.

Since activation of Bid turned out to be downstream of caspase activation and Puma was not essential for Celecoxib-induced apoptosis, we next analyzed the role of Bim. Bim preferentially interacted with Bcl-2 and Mcl-1, but less with Bcl-xL in Jurkat cells (Fig 4A, left panel). Reverse precipitation of $\mathrm{Bcl}-2$, Bcl-xL, and Mcl-1 confirmed the binding of Bim to the analyzed anti-apoptotic proteins.(Fig. 4A, middle and right panels). In Bcl-2overexpressing cells, an association of Bim with Mcl-1 or Bcl-xL is hardly detectable (Fig 4B). Bcl-2 crowded Mcl-1 and Bcl-xL from its interaction with Bim. In contrast, overexpression of Bcl-xL did not affect the binding of $\mathrm{Bcl}-2$ to $\mathrm{Bim}$ but $\mathrm{Bcl}-\mathrm{xL}$ was able to supplant Mcl-1 to lesser extent.

After stimulation with $75 \mu \mathrm{M}$ Celecoxib, no change of interaction could be observed between Bcl-2 and Bim in Jurkat cells (Fig. 4A). Although a reduced interaction of Bcl-xL with Bim 
and Mcl-1 with Bim was noticed in response to Celecoxib, an enhanced association of the released Bim with the multi-domain protein Bak could not be detected. The results point to an ancillary role of Bim during Celecoxib-induced Bak activation and $\Delta \Psi \mathrm{m}$ dissipation. Silencing of Bim by siRNA should reassess the assumption. Successful downregulation of Bim by siRNA was verified $48 \mathrm{~h}$ later by Western blotting (Fig. 4C). Thus, $48 \mathrm{~h}$ after electroporation of Jurkat cells with bim or the non-targeting control siRNA, cells were stimulated with 50-100 $\mu \mathrm{M}$ Celecoxib for 6h. Surprisingly, Celecoxib triggered apoptosis (Fig.4D) and $\Delta \Psi \mathrm{m}$ dissipation (Fig. 4E) with similar sensitivity in Jurkat cells irrespective of Bim levels. A slight protection by bim siRNA was only observed when cells were treated with $75 \mu \mathrm{M}$ Celecoxib. The experiments indicate that, similar to Puma, Bim was not needed either for Celecoxib-induced apoptosis.

The separate silencing of Bim and Puma showed that none of those two BH3-only proteins is essential for Celecoxib-induced apoptosis in Jurkat cell, but it does not exclude a redundant function of Bim and Puma. Therefore, the expression of both proteins was silenced by siRNA before treatment with 50-100 $\mu \mathrm{M}$ Celecoxib for $6 \mathrm{~h}$. However, simultaneous silencing of Bim and Puma was without effect on Celecoxib-induced apoptosis (Fig. 5A) and $\Delta \Psi \mathrm{m}$ dissipation (Fig. 5B).

Taken together, our experiments excluded a essential or redundant role of Bid, Bim, and Puma in mitochondrial permeabilization during apoptosis induction by Celecoxib.

\subsection{Nur77/TR3 does not target Bcl-2 during Celecoxib-induced apoptosis}

Since none of the examined BH3-only proteins were needed for Celecoxib-induced apoptosis, the different sensitivity, the regulation of Bcl-2 and Bcl-xL by those $\mathrm{BH} 3$-only proteins was implausible. There have to be other interaction partners of the anti-apoptotic proteins which explain the different sensitivity of Bcl-2- and Bcl-xL-overexpressing cells towards Celecoxib. 
Recent publications described the protein Nur77/TR3 which specifically binds to Bcl-2 but not Bcl-xL [23]. In a complex with Nur77/TR3, Bcl-2 loses its protective function. Thus, in the next set of experiment we examined the role of Nur77/TR3 during Celecoxib-induced apoptosis. However, an upregulation of Nur77/TR3 in response to Celecoxib was not observed (Fig. 6A). Neither could we detect an interaction between Nur77/TR3 and Bcl-2 (Fig. 6B). Thus, an involvement of Nur77/TR3 during Celecoxib-induced apoptosis could be excluded.

\subsection{Bcl-2 and Bcl-xL differ in their interaction with Bak}

Since Bcl-2 and Bcl-xL showed different affinities for Bim, we hypothesized that those two similar anti-apoptotic proteins could also vary in their binding to Bak. Coimmunoprecipitation studies with an antibody that preferably recognized the active conformation of Bak as well as with antibodies against Mcl-1, Bcl-2, and Bcl-xL revealed that Bak interacted primarily with Mcl-1 and Bcl-xL (Fig. 7A, left panel). Bcl-2:Bak complexes were not detected in healthy Jurkat vector cells, nor in cells treated with Celecoxib. In Bcl-xLoverexpressing cells, more Bak co-precipitated with Bcl-xL than in Jurkat Vector controls (Fig. 7A, right panel). In total, however, less Bak was precipitated with the activation specific antibody when compared to Jurkat vector or Bcl-2 overexpressing cells confirming previous observations that $\mathrm{Bcl}-\mathrm{xL}$ inhibits Celecoxib-induced Bak activation and $\Delta \Psi \mathrm{m}$ dissipation. Surprisingly, Bak was also co-precipitated with Bcl-2 in cells overexpressing Bcl-2 (Fig. 7A, middle panel). To estimate the affinity of the Bak interaction with the three different antiapoptotic proteins, we changed the lysis conditions. The use of the much stronger detergent Triton X-100 instead of the mild CHAPS averted complex formation between Bcl-2 and Bak (Fig. 7B). In contrast, Bcl-xL and Mcl-1 co-precipitated with Bak even under harsher lysis conditions. Similar results were obtained when Triton X-100 was reduced from $1 \%$ to $0.2 \%$. 
The last experiments indicate that the interaction of Bak with Bcl-xL or Mcl-1 differs from that of Bak with Bcl-2.

Taken together, the results show that Bcl-2 and Bcl-xL do not interact in the same way with Bak in Jurkat cells. The different affinities to Bak might also explain why Bcl-2, in contrast to Bcl-xL, did not protect from Celecoxib-induced apoptosis. 


\section{Discussion:}

Members of the Bcl-2 protein family are important regulators of survival and death during apoptosis induction through the intrinsic pathway. Many cytotoxic drugs as well as the COX2 inhibitor Celecoxib, ionizing radiation, growth factor withdrawal, and severe hypoxia initiate apoptosis through the mitochondrial pathway [11, 24-27]. Overexpression of antiapoptotic proteins or inefficient activation of the pro-apoptotic ones improves cellular survival and accounts for resistance against diverse anti-cancer therapies.

Here we show that the Celecoxib-induced apoptosis could be blocked by overexpression of Bcl-xL but not by the closely related Bcl-2 in Jurkat cells. Mcl-1 and Bcl-xL tightly associated with Bak in healthy Jurkat cells. In contrast, Bcl-2:Bak complexes were detectable in Bcl-2-overexpressing cells and under mild lysis conditions only. We conclude that the strong interaction between Bcl-xL and Bak kept Bak in an inactive conformation thereby protecting from mitochondrial permeabilization and apoptosis induction by Celecoxib in Bcl$\mathrm{xL}$-overexpressing cells whereas Bcl-2, incapable of such interaction, did not interfere with Celecoxib-induced apoptosis. Our data provide strong evidence that Bcl-xL and Bcl-2 do not use the same mechanism to interfere with apoptosis induction in Jurkat cells.

\subsection{Celecoxib: an apoptosis-inducing drug}

Celecoxib is a selective COX-2 inhibitor which effectively induces apoptosis by a mechanism yet unknown. The inhibitory and cytotoxic effects could be mapped to different structural characteristics of the molecule and therefore occur independently [28]. The mechanism by which Celecoxib induces apoptosis is not well understood. Celecoxib and its derivates without COX-2 inhibitory function were shown to induce aggravated endoplasmatic stress with subsequent caspase activation. Celecoxib and the related OSU-03012 could also interfere with the PKB/Akt survival pathway [29, 30]. Moreover, Celecoxib, but not the other coxibes 
Rofecoxib and Valdecoxib, can inhibit protein translation transiently with subsequent downregulation of short-lived proteins [31]. Previous result in our lab revealed that Celecoxib facilitated a rapid downregulation of the anti-apoptotic Mcl-1. Lowering the expression levels of the anti-apoptotic Mcl-1 was sufficient for apoptosis induction through the intrinsic pathway [7]. In addition, using an antibody in immunoprecipitation studies which recognized preferentially the active conformation of Bak, we now show that Celecoxib induced a rapid activation of Bak in Jurkat Vector and Bcl-2-overexpressing cells but not in Bcl-xLoverexpressing cells.

\subsection{Bcl-2 and Bcl-xL: similarities and differences}

The Bcl-2 protein family was divided into three subgroups according to the similarities in structure and function: the anti-apoptotic proteins which sequester the pro-apoptotic ones, the pro-apoptotic multidomain proteins whose activation is required during intrinsic apoptosis, and the $\mathrm{BH} 3$-only proteins which regulate the activation of the multidomain and neutralize the anti-apoptotic ones [17]. Previous publications have shown that the $\mathrm{Bcl}-2$ family members within a subgroup can fulfill a redundant role during apoptosis induction [32, 33]. Newer data, however, point to a more complex mutual regulation of the pro- and anti-apoptotic Bcl-2 family members. Especially the anti-apoptotic Bcl-2 and its close relative Bcl-xL were thought to be exchangeable. Both proteins maintain mitochondrial homeostasis during apoptosis induction in response to ionizing radiation, hypoxia, cytotoxic drugs, and growth factor withdrawal, whereas both proteins did not affect death receptor induced apoptosis [24, 25, 34-36]. Despite their similarities, Bcl-2- and Bcl-xL-deficient mice have a different phenotype indicating the regulation of distinct processes [37, 38]. Expression of either Bcl-2 or Bcl-xL in hematopoietic progenitor cells commits to differentiation to erythroid or myolid cells respectively [39]. Also, a switch of expression was observed during tumor progression in 
melanoma cells when Mcl-1 and Bcl-xL were up-regulated whereas Bcl-2 was downregulated [40].

Our data emphasize the differences between the similar Bcl-2 and Bcl-xL showing that overexpression of Bcl-xL but not Bcl-2 inhibited Celecoxib-induced apoptosis in Jurkat $\mathrm{T}$ lymphoma cells.

\subsection{Role of Nur77/TR3 during Celecoxib-induced apoptosis}

The aim of the present study was the analysis of the mechanism leading to neutralization of Bcl-2 but not Bcl-xL during Celecoxib-induced apoptosis. In this regard, the specific interaction of the orphan nuclear receptor Nur77/TR3 was described. In response to some anti-neoplastic drugs, Nur77/TR3 translocates from nucleus to mitochondria where it interacts with Bcl-2 transforming the anti-apoptotic molecule into a pro-apoptotic one [21]. Nur77 is expressed and upregulated in response to phorbol acetate and calcium ionophore in Jurkat cells [23]. Although having confirmed the expression of Nur77/TR3 protein in Jurkat cells, neither an upregulation of the orphan receptor nor its binding to $\mathrm{Bcl}-2$ was observed during Celecoxib-induced apoptosis. Thus, the lack of protection of Bcl-2 during Celecoxib-induced apoptosis was not due to an interaction of Bcl-2 with Nur77/TR3.

\subsection{BH3-only proteins during Celecoxib-induced apoptosis}

The different protective properties of Bcl-2 and Bcl-xL might also be explained by distinct binding preferences to other Bcl-2 family members. Bcl-2 and Bcl-xL bind to the $\mathrm{BH} 3$-only proteins Bad and Bmf whereas they do not interact with Noxa [18, 41]. In this regard, the two survival-promoting proteins differ completely from the anti-apoptotic Bcl-2 family members Mcl-1 and A1 which display complementary binding preferences. In contrast, activated Bid associates rather with $\mathrm{Bcl}-\mathrm{xL}$ than with $\mathrm{Bcl}-2$ [18]. Bid must be cleaved by caspases to become activated. During apoptosis induction through the extrinsic pathway, caspases are 
activated at the death receptor signaling complex prior to $\Delta \Psi \mathrm{m}$ dissipation whereas, during induction of intrinsic apoptosis, they become activated after $\Delta \Psi \mathrm{m}$ dissipation $[24,42]$. Since the pan-caspase inhibitor blocked Bid activation without affecting Celecoxib-stimulated $\Delta \Psi \mathrm{m}$ dissipation we concluded that Bid plays no role in initial mitochondrial permeabilization. Moreover, due to the low-affinity binding to Bcl-2, it is unlikely that tBid neutralized only Bcl-2 during Celecoxib-induced apoptosis [18].

Puma was described as a BH3-only protein with broad binding spectrum to all anti-apoptotic proteins [41]. Although it is expressed in healthy Jurkat cells, we did not detect any association of Puma with anti-apoptotic proteins or with Bak during Celecoxib-induced apoptosis. Interestingly, Puma is downregulated during Celecoxib-induced apoptosis. The downregulation of Puma was caspase-dependent since it was blocked by the pan-caspase inhibitor zVAD. Thus, the decline of Puma is rather a consequence of apoptosis induction by Celecoxib and of no importance for the initial mitochondrial permeabilization.

Like Puma, Bim was described to have a similar broad binding spectrum to other antiapoptotic Bcl-2 family members [18, 41]. In our cell system, however, Bim preferred Bcl-2 to Mcl-1 and Bcl-xL. Although Bim is released from its sequestration by Mcl-1 and Bcl-xL during Celecoxib-induced apoptosis, the interaction between Bcl-2 and Bim was not altered during the course. Binding of Bim to Bak in response to Celecoxib was not observed in our cell system. Moreover, siRNA-mediated downregulation of Bim and Puma showed convincingly that neither Bim nor Puma were essential for Celecoxib-induced apoptosis. In contrast, silencing of Bim or Puma improved the survival or Jurkat cells after growth factor withdrawal (Fig. S2) which is in accordance with observations made earlier [32, 43, 44]. Taken together, our data indicate that the BH3-only proteins Puma, Bid, and Bim are dispensable for the initial mitochondrial permeabilization during Celecoxib-induced apoptosis. 


\subsection{Interaction with Bak during Celecoxib-induced apoptosis}

Since the interaction between anti-apoptotic Bcl-2 family members and activator BH3-only proteins is of minor importance, we propose the displacement model for Celecoxib-induced apoptosis. This model suggests a sequestration of multidomain proteins by the anti-apoptotic Bcl-2 family members $[15,18,45,46]$. Binding of the appropriate $\mathrm{BH} 3$-only proteins to antiapoptotic ones displaces the Bax/Bak-like proteins allowing their activation.

Jurkat T lymphoma cells do not express Bax but Bak $[12,47]$. Thus, the activation of Bak is essential for Celecoxib-induced apoptosis [13]. Our data show an interaction of Bak with Mcl-1 or Bcl-xL in Jurkat Vector as well as in the Bcl-2 and Bcl-xL-overexpressing cells. Using mild lysis condition, Bcl-2:Bak complexes were also detected in Bcl-2-overexpressing cells. However, the association of Mcl-1 or Bcl-xL with Bak was obviously different from that of Bcl-2 with Bak. In contrast to Bcl-2, Bcl-xL and Mcl-1 form complexes even under harsher lysis conditions when $0.2 \%$ and $1 \%$ Triton $\mathrm{X}-100$ was used suggesting a much stronger interaction between the latter ones and Bak than between Bcl-2 and Bak. The use of Triton X-100 is not unproblematic. Previous publications showed that immunoprecipitation of Bax and the heterodimerization with anti-apoptotic proteins depends on the detergent used [48]. In addition, Hsu and Youle detected a heterodimerization of Bax with Bcl-2 and Bcl-xL in presence of Triton X-100 but not CHAPS [48]. Contrary to this previous publication, using different concentrations of Triton $\mathrm{X}-100$, our results show that the detergent did not facilitate the binding of the anti-apoptotic Mcl-1 and Bcl-xL to Bak but prevented interaction between Bcl-2 and Bak. Interestingly, Bak was easily precipitated in presence of Triton X-100, and the amount of precipitated Bak did not change over time after treatment with Celecoxib (data not shown). In presence of CHAPS, in contrast, we were hardly able to precipitate Bak in healthy cells. Probably, Triton X-100 interfered with intramolecular interactions of Bak facilitating the exposure of its $\mathrm{N}$-terminus and, therefore, its precipitation with an antibody recognizing the $\mathrm{N}$-terminus. This effect was not observed 
when the milder detergent CHAPS was used. The N-terminal exposure is a step during Bak activation that precedes Bak oligomerization. In this case, Triton X-100 would allow the association of Mcl-1 and Bcl-xL, but not Bcl-2, with a "partially activated" Bak. The specificity of Bak for Mcl-1 and Bcl-xL was described earlier [49, 50]. Both publications did not detect any interaction of Bcl-2 with Bak. Thus, Mcl-1 and Bcl-xL protected from apoptosis by sequestration of the pro-apoptotic Bak whereas Bcl-2 did not. Yet, Bcl-2 appears to use other mechanism to protect from apoptosis induced by overexpression of Bax and Bak [50]. Interestingly, our Jurkat cells overexpressing Bcl-2 and Bcl-xL also inhibited apoptosis induction in response to ionizing radiation in earlier experiments [24, 51]. Although Bcl-2 is not capable of effective Bak sequestration, still it could bind to and neutralize other proapoptotic BH3-only family members including Bim, Puma, Bad, and Bmf.

Regarding our data, we suggest following mechanisms for Celecoxib-induced apoptosis: in Jurkat T lymphoma cells, pro-apoptotic Bak is sequestered by Bcl-xL and Mcl-1. Treatment with Celecoxib induces a rapid downregulation of Mcl-1 protein levels which is sufficient to activate Bak. Overexpression of Bcl-xL protects from apoptosis because Bcl-xL can substitute for Mcl-1 loss by sequestering Bak which was released after Mcl-1 downregulation.

Overexpression of Bcl-2 fails to inhibit Celecoxib-induced apoptosis because of inaptness to interact with Bak. The different association preferences of Bcl-2 and Bcl-xL with other proapoptotic Bcl-2 family members observed in our experiments allow the conclusion that Bcl$\mathrm{xL}$ and $\mathrm{Bcl}-2$ use different mechanisms to protect from apoptosis in response to distinct stimuli. 


\section{Disclosure of potential conflicts of interests}

The authors declare no conflict of interests.

\section{Acknowledgments}

The work was supported by grants from the fortüne-Program of the University of Tübingen (1806-1-0) and from the German Research Foundation DFG (1641/1-1) to JR. Pharmacia Pfizer kindly provided Celecoxib for our study.

\section{Contributions}

JR designed the study and contributed most of the experimental work, analyzed and interpreted the data, drafted and revised the manuscript and gave the final approval. SJE contributed significantly to data acquisition and analysis. VJ and SMH helped drafting and revising the manuscript. In addition, SMH helped with data analysis and interpretation. 


\section{References:}

[1] Grosch S, Tegeder I, Niederberger E, Brautigam L, Geisslinger G. COX-2 independent induction of cell cycle arrest and apoptosis in colon cancer cells by the selective COX-2 inhibitor celecoxib. Faseb J 2001;15:2742-4.

[2] Uchida K. A lipid-derived endogenous inducer of COX-2: a bridge between inflammation and oxidative stress. Mol Cells 2008;25:347-51.

[3] Zha S, Yegnasubramanian V, Nelson WG, Isaacs WB, De Marzo AM. Cyclooxygenases in cancer: progress and perspective. Cancer Lett 2004;215:1-20.

[4] Phillips RK, Wallace MH, Lynch PM, Hawk E, Gordon GB, Saunders BP, et al. A randomised, double blind, placebo controlled study of celecoxib, a selective cyclooxygenase 2 inhibitor, on duodenal polyposis in familial adenomatous polyposis. Gut 2002;50:857-60.

[5] Steinbach G, Lynch PM, Phillips RK, Wallace MH, Hawk E, Gordon GB, et al. The effect of celecoxib, a cyclooxygenase-2 inhibitor, in familial adenomatous polyposis. $\mathrm{N}$ Engl J Med 2000;342:1946-52.

[6] Kardosh A, Wang W, Uddin J, Petasis NA, Hofman FM, Chen TC, et al. Dimethylcelecoxib (DMC), a derivative of celecoxib that lacks cyclooxygenase-2-inhibitory function, potently mimics the anti-tumor effects of celecoxib on Burkitt's lymphoma in vitro and in vivo. Cancer Biol Ther 2005;4:571-82.

[7] Rudner J, Elsaesser SJ, Muller AC, Belka C, Jendrossek V. Differential effects of antiapoptotic Bcl-2 family members Mcl-1, Bcl-2, and Bcl-xL on celecoxib-induced apoptosis. Biochem Pharmacol 2010;79:10-20.

[8] Pyrko P, Soriano N, Kardosh A, Liu YT, Uddin J, Petasis NA, et al. Downregulation of survivin expression and concomitant induction of apoptosis by celecoxib and its noncyclooxygenase-2-inhibitory analog, dimethyl-celecoxib (DMC), in tumor cells in vitro and in vivo. Mol Cancer 2006;5:19.

[9] Kardosh A, Golden EB, Pyrko P, Uddin J, Hofman FM, Chen TC, et al. Aggravated endoplasmic reticulum stress as a basis for enhanced glioblastoma cell killing by bortezomib in combination with celecoxib or its non-coxib analogue, 2,5-dimethylcelecoxib. Cancer Res 2008;68:843-51.

[10] Gao M, Yeh PY, Lu YS, Hsu CH, Chen KF, Lee WC, et al. OSU-03012, a novel celecoxib derivative, induces reactive oxygen species-related autophagy in hepatocellular carcinoma. Cancer Res 2008;68:9348-57.

[11] Jendrossek V, Handrick R, Belka C. Celecoxib activates a novel mitochondrial apoptosis signaling pathway. Faseb J 2003;17:1547-9.

[12] Muller AC, Handrick R, Elsaesser SJ, Rudner J, Henke G, Ganswindt U, et al. Importance of Bak for celecoxib-induced apoptosis. Biochem Pharmacol 2008;76:108296.

[13] Rudner J, Mueller AC, Matzner N, Huber SM, Handrick R, Belka C, et al. The additional loss of Bak and not the lack of the protein tyrosine kinase p56/Lck in one JCaM1.6 subclone caused pronounced apoptosis resistance in response to stimuli of the intrinsic pathway. Apoptosis 2009;14:711-20.

[14] Adams JM. Ways of dying: multiple pathways to apoptosis. Genes Dev 2003;17:248195.

[15] Galonek HL, Hardwick JM. Upgrading the BCL-2 network. Nat Cell Biol 2006;8:13179.

[16] Adams JM, Cory S. The Bcl-2 apoptotic switch in cancer development and therapy. Oncogene 2007;26:1324-37. 
[17] Youle RJ, Strasser A. The BCL-2 protein family: opposing activities that mediate cell death. Nat Rev Mol Cell Biol 2008;9:47-59.

[18] Chen L, Willis SN, Wei A, Smith BJ, Fletcher JI, Hinds MG, et al. Differential targeting of prosurvival Bcl-2 proteins by their BH3-only ligands allows complementary apoptotic function. Mol Cell 2005; 17:393-403.

[19] Kim H, Rafiuddin-Shah M, Tu HC, Jeffers JR, Zambetti GP, Hsieh JJ, et al. Hierarchical regulation of mitochondrion-dependent apoptosis by BCL-2 subfamilies. Nat Cell Biol 2006;8:1348-58.

[20] Letai A, Bassik MC, Walensky LD, Sorcinelli MD, Weiler S, Korsmeyer SJ. Distinct $\mathrm{BH} 3$ domains either sensitize or activate mitochondrial apoptosis, serving as prototype cancer therapeutics. Cancer Cell 2002;2:183-92.

[21] Lin B, Kolluri SK, Lin F, Liu W, Han YH, Cao X, et al. Conversion of Bcl-2 from protector to killer by interaction with nuclear orphan receptor Nur77/TR3. Cell 2004;116:527-40.

[22] Gary-Gouy H, Sainz-Perez A, Bismuth G, Ghadiri A, Perrino BA, Dalloul A. Cyclosporin-A inhibits ERK phosphorylation in B cells by modulating the binding of Raf protein to Bcl2. Biochem Biophys Res Commun 2006;344:134-9.

[23] Li H, Kolluri SK, Gu J, Dawson MI, Cao X, Hobbs PD, et al. Cytochrome c release and apoptosis induced by mitochondrial targeting of nuclear orphan receptor TR3. Science 2000;289:1159-64.

[24] Belka C, Rudner J, Wesselborg S, Stepczynska A, Marini P, Lepple-Wienhues A, et al. Differential role of caspase- 8 and BID activation during radiation- and CD95-induced apoptosis. Oncogene 2000;19:1181-90.

[25] Weinmann M, Jendrossek V, Handrick R, Guner D, Goecke B, Belka C. Molecular ordering of hypoxia-induced apoptosis: critical involvement of the mitochondrial death pathway in a FADD/caspase-8 independent manner. Oncogene 2004;23:3757-69.

[26] You H, Pellegrini M, Tsuchihara K, Yamamoto K, Hacker G, Erlacher M, et al. FOXO3a-dependent regulation of Puma in response to cytokine/growth factor withdrawal. J Exp Med 2006;203:1657-63.

[27] McGrogan BT, Gilmartin B, Carney DN, McCann A. Taxanes, microtubules and chemoresistant breast cancer. Biochim Biophys Acta 2008;1785:96-132.

[28] Schonthal AH, Chen TC, Hofman FM, Louie SG, Petasis NA. Celecoxib analogs that lack COX-2 inhibitory function: preclinical development of novel anticancer drugs. Expert Opin Investig Drugs 2008;17:197-208.

[29] Zhu J, Huang JW, Tseng PH, Yang YT, Fowble J, Shiau CW, et al. From the cyclooxygenase-2 inhibitor celecoxib to a novel class of 3-phosphoinositide-dependent protein kinase-1 inhibitors. Cancer Res 2004;64:4309-18.

[30] Paik YH, Kim JK, Lee JI, Kang SH, Kim DY, An SH, et al. Celecoxib induces hepatic stellate cell apoptosis through inhibition of Akt activation and suppresses hepatic fibrosis in rats. Gut 2009;58:1517-27.

[31] Pyrko P, Kardosh A, Schonthal AH. Celecoxib transiently inhibits cellular protein synthesis. Biochem Pharmacol 2008;75:395-404.

[32] Jabbour AM, Heraud JE, Daunt CP, Kaufmann T, Sandow J, O'Reilly LA, et al. Puma indirectly activates Bax to cause apoptosis in the absence of Bid or Bim. Cell Death Differ 2009;16:555-63.

[33] Hemmati PG, Guner D, Gillissen B, Wendt J, von Haefen C, Chinnadurai G, et al. Bak functionally complements for loss of Bax during p14ARF-induced mitochondrial apoptosis in human cancer cells. Oncogene 2006;25:6582-94.

[34] Reeve JL, Szegezdi E, Logue SE, Chonghaile TN, O'Brien T, Ritter T, et al. Distinct mechanisms of cardiomyocyte apoptosis induced by doxorubicin and hypoxia converge on mitochondria and are inhibited by Bcl-xL. J Cell Mol Med 2007;11:509-20. 
[35] Altman BJ, Wofford JA, Zhao Y, Coloff JL, Ferguson EC, Wieman HL, et al. Autophagy provides nutrients but can lead to Chop-dependent induction of Bim to sensitize growth factor-deprived cells to apoptosis. Mol Biol Cell 2009;20:1180-91.

[36] Ugarenko M, Nudelman A, Rephaeli A, Kimura K, Phillips DR, Cutts SM. ABT-737 overcomes Bcl-2 mediated resistance to doxorubicin-DNA adducts. Biochem Pharmacol 2010;79:339-49.

[37] Veis DJ, Sorenson CM, Shutter JR, Korsmeyer SJ. Bcl-2-deficient mice demonstrate fulminant lymphoid apoptosis, polycystic kidneys, and hypopigmented hair. Cell 1993;75:229-40.

[38] Motoyama N, Wang F, Roth KA, Sawa H, Nakayama K, Nakayama K, et al. Massive cell death of immature hematopoietic cells and neurons in Bcl-X-deficient mice. Science 1995;267:1506-10.

[39] Haughn L, Hawley RG, Morrison DK, von Boehmer H, Hockenbery DM. BCL-2 and BCL-XL restrict lineage choice during hematopoietic differentiation. J Biol Chem 2003;278:25158-65.

[40] Zhuang L, Lee CS, Scolyer RA, McCarthy SW, Zhang XD, Thompson JF, et al. Mcl-1, $\mathrm{Bcl}-\mathrm{XL}$ and Stat 3 expression are associated with progression of melanoma whereas Bcl2, AP-2 and MITF levels decrease during progression of melanoma. Mod Pathol 2007;20:416-26.

[41] Labi V, Erlacher M, Kiessling S, Villunger A. BH3-only proteins in cell death initiation, malignant disease and anticancer therapy. Cell Death Differ 2006;13:1325-38.

[42] Li H, Zhu H, Xu CJ, Yuan J. Cleavage of BID by caspase 8 mediates the mitochondrial damage in the Fas pathway of apoptosis. Cell 1998;94:491-501.

[43] Ekoff M, Kaufmann T, Engstrom M, Motoyama N, Villunger A, Jonsson JI, et al. The $\mathrm{BH} 3-$ only protein Puma plays an essential role in cytokine deprivation induced apoptosis of mast cells. Blood 2007;110:3209-17.

[44] Erlacher M, Michalak EM, Kelly PN, Labi V, Niederegger H, Coultas L, et al. BH3only proteins Puma and Bim are rate-limiting for gamma-radiation- and glucocorticoidinduced apoptosis of lymphoid cells in vivo. Blood 2005;106:4131-8.

[45] Willis SN, Fletcher JI, Kaufmann T, van Delft MF, Chen L, Czabotar PE, et al. Apoptosis initiated when BH3 ligands engage multiple Bcl-2 homologs, not Bax or Bak. Science 2007;315:856-9.

[46] Shimazu T, Degenhardt K, Nur EKA, Zhang J, Yoshida T, Zhang Y, et al. NBK/BIK antagonizes MCL-1 and BCL-XL and activates BAK-mediated apoptosis in response to protein synthesis inhibition. Genes Dev 2007;21:929-41.

[47] Lopez-Royuela N, Perez-Galan P, Galan-Malo P, Yuste VJ, Anel A, Susin SA, et al. Different contribution of BH3-only proteins and caspases to doxorubicin-induced apoptosis in p53-deficient leukemia cells. Biochem Pharmacol 2010;79:1746-58.

[48] Hsu YT, Youle RJ. Bax in murine thymus is a soluble monomeric protein that displays differential detergent-induced conformations. J Biol Chem 1998;273:10777-83.

[49] Willis SN, Chen L, Dewson G, Wei A, Naik E, Fletcher JI, et al. Proapoptotic Bak is sequestered by Mcl-1 and Bcl-xL, but not Bcl-2, until displaced by BH3-only proteins. Genes Dev 2005;19:1294-305.

[50] Zhai D, Jin C, Huang Z, Satterthwait AC, Reed JC. Differential regulation of Bax and Bak by anti-apoptotic Bcl-2 family proteins Bcl-B and Mcl-1. J Biol Chem 2008;283:9580-6.

[51] Rudner J, Lepple-Wienhues A, Budach W, Berschauer J, Friedrich B, Wesselborg S, et al. Wild-type, mitochondrial and ER-restricted Bcl-2 inhibit DNA damage-induced apoptosis but do not affect death receptor-induced apoptosis. J Cell Sci 2001;114:416172 . 


\section{Legends:}

\section{Figure 1: Overexpression of Bcl-xL but not Bcl-2 protects from Celecoxib-induced}

apoptosis. Jurkat Vector cells and Jurkat cells overexpressing Bcl-2 and Bcl-xL were treated with 50, 75, or $100 \mu \mathrm{M}$ Celecoxib. 6h later apoptosis induction was analyzed after Annexin V/propidium iodide (AnnV/PI) double staining by flow cytometry (A). At the same time the dissipation of the mitochondrial membrane potential $(\Delta \Psi \mathrm{m})$ was estimated with the potential sensitive dye TMRE by flow cytometry (B). Apoptosis and $\Delta \Psi \mathrm{m}$ dissipation was induced in a concentration-dependent manner in Jurkat Vector and Bcl-2 cells whereas it was clearly inhibited by overexpression of Bcl-xL. (C) The ED50 values for Celecoxib concentrations were calculated as described in the "Material and methods" section. Left panel shows the ED50 values obtained from measuring healthy cells (AnnV-/PI-), right panel shows the ED50 values obtained from measuring cells with dissipated membrane potential (low $\Delta \Psi \mathrm{m})$. The ED50 values were similar for Jurkat Vector and Bcl-2-overexpressing cells and significantly higher for Bcl-xL-overexpressing cells (***: p<0.001). (D) Activation of caspase-9, caspase3, caspase-8, and cleavage of the caspase-3 substrate PARP as well as the expression levels of the Bcl-2 family members Mcl-1, Bcl-2, Bcl-xL, and Bak after treatment with $75 \mu \mathrm{M}$ Celecoxib were detected by Western blotting. Caspases were activated already $3 \mathrm{~h}$ after treatment with Celecoxib in Jurkat Vector and Bcl-2 cells but not in Jurkat Bcl-xL cells. Mcl1 was downregulated in all three cell lines as early as $3 \mathrm{~h}$ in response to Celecoxib whereas the expression levels of Bcl-2, Bcl-xL, and Bak remained unchanged.

\section{Figure 2: Changes of the BH3-only proteins Bim, Puma and Bid during Celecoxib-}

induced apoptosis. (A) Jurkat Vector cells and Jurkat cells overexpressing Bcl-2 and Bcl-xL were treated with $75 \mu \mathrm{M}$ Celecoxib for $3 \mathrm{~h}$ and $6 \mathrm{~h}$. Western blot analysis shows that Bim expression levels remained unchanged during Celecoxib-induced apoptosis. However, a late 
decline of Puma and early cleavage of Bid was detected in Jurkat Vector and Bcl-2overexpressing cells. (B, C) Jurkat Vector cells were co-treated with $30 \mu \mathrm{M}$ of caspase inhibitor zVAD-fmk and $75 \mu \mathrm{M}$ Celecoxib. (B) Treatment with zVAD-fmk prevented Celecoxib-induced apoptosis (B, left panel) and processing of caspase-9, caspase-3, caspase8, and PARP (C) but had no effect on $\Delta \Psi \mathrm{m}$ dissipation (B, right panel). (C) Decline of Puma and Bid cleavage were prevented by inhibition of caspases whereas downregulation of Mcl-1 was still observed in presence of zVAD-fmk. Tubulin was used as loading control.

Figure 3: BH3-only Puma is not essential for Celecoxib-induced apoptosis. (A) Jurkat E6.1 cells were electroporated with $0.5-2 \mu \mathrm{M}$ puma siRNA. $48 \mathrm{~h}$ later, downregulation of Puma was examined by Western blotting and analyzed densitometrically. (B, C) Jurkat E6.1 cells were transfected with $1 \mu \mathrm{M}$ non-targeting (nt) or puma siRNA for $48 \mathrm{~h}$ before treatment with 50-100 $\mu \mathrm{M}$ Celecoxib for 6h. Downregulation of Puma did not affect induction of apoptosis (B) and $\Delta \Psi$ m dissipation (C). (D) Left panel: Immunoprecipitation (IP) studies with antibodies against Bak, Mcl-1, Bcl-xL, and Bcl-2 were performed in Jurkat E6.1 cells treated with $75 \mu \mathrm{M}$ Celecoxib for $3 \mathrm{~h}$ and $6 \mathrm{~h}$. Right panel: whole cell lysates (WCL) from the respective experiments were separated by western blotting. BH3-only Puma did not coprecipitate with Bak, Mcl-1, Bcl-xL, or Bcl-2.

Figure 4: BH3-only Bim is not essential for Celecoxib-induced apoptosis. (A) Jurkat E6.1 cells were treated with $75 \mu \mathrm{M}$ Celecoxib for $3 \mathrm{~h}$ and $6 \mathrm{~h}$ before immunoprecipitation (IP) studies were performed. Immunoprecipitation of Bim (left panel), Bcl-2 (middle, upper panel), Bcl-xL (right, upper panel), Mcl-1 (middle, lower panel), and Bak (right, lower panel) shows that Bim interacted preferentially with Bcl-2 but also with Mcl-1 and Bcl-xL. A change of interaction from anti-apoptotic Bcl-2 family members to Bak was not observed during Celecoxib-induced apoptosis. (B) Bim was precipitated in lysates from untreated Jurkat 
Vector, Bcl-2, and Bcl-xL cells. When overexpressed, Bcl-2 supercedes Bcl-xL and Mcl-1 in complex with Bim. In contrast, overexpressed Bcl-xL cannot replace Bcl-2. (C) Jurkat E6.1 cells were electroporated with $0.25-1 \mu \mathrm{M}$ bim siRNA. $48 \mathrm{~h}$ later, downregulation of Bim was examined by Western blotting and analyzed densitometrically. (D, E) Jurkat E6.1 cells were transfected with $250 \mathrm{nM}$ bim siRNA or non-targeting (nt) siRNA, respectively. After $48 \mathrm{~h}$, cells were treated with 50-100 $\mu \mathrm{M}$ Celecoxib for $6 \mathrm{~h}$ before flow cytometric analysis. Induction of apoptosis (D) and $\Delta \Psi \mathrm{m}$ dissipation (E) were not affected by silencing of Bim.

\section{Figure 5: Bim and Puma have no redundant function during Celecoxib-induced} apoptosis in Jurkat cells. To exclude a redundant function of Bim and Puma, Jurkat cells were electroporated with $0.25 \mu \mathrm{M}$ bim siRNA and $1 \mu \mathrm{M}$ puma siRNA or with $1.25 \mu \mathrm{M}$ nontargeting (nt) siRNA for $48 \mathrm{~h}$ before treatment with 50-100 $\mu \mathrm{M}$ Celecoxib for $6 \mathrm{~h}$. No change of apoptosis induction (A) and $\Delta \Psi \mathrm{m}$ dissipation (B) was observed when Bim and Puma were concurrently downregulated.

\section{Figure 6: The orphan nuclear receptor Nur77/TR3 does not bind to Bcl-2 during}

Celecoxib-induced apoptosis. Jurkat Vector and Bcl-2 cells were treated with $75 \mu \mathrm{M}$ Celecoxib for $3 \mathrm{~h}$ and $6 \mathrm{~h}$. (A) Western blot analysis shows that the orphan nuclear receptor Nur77/TR3 was not upregulated during Celecoxib-induced apoptosis. (B) Immunoprecipitaion of Bcl-2 in Jurkat vector cells (left panel) and Bcl-2 overexpressing cells (middle panel) shows that Nur77/TR3 did not co-precipitate with Bcl-2 in response to Celecoxib. Right panel: whole cell lysates of respective untreated cells show the expression levels of Bcl-2 and endogenous Nur77/TR3.

Figure 7: Mcl-1 and Bcl-xL but not Bcl-2 associate tightly with Bak to prevent its activation. (A) Jurkat Vector (left), Jurkat Bcl-2 (middle), and Jurkat Bcl-xL cells (right) 
were treated with $75 \mu \mathrm{M}$ Celecoxib for $3 \mathrm{~h}$ and $6 \mathrm{~h}$. Immunoprecipitation was performed with antibodies against Mcl-1, Bcl-2, Bcl-xL, and Bak (IP from top to bottom) after cell lysis with $1 \%$ CHAPS. Using an antibody which preferentially recognizes the active conformation of Bak, a considerable increase of Bak could be precipitated in Jurkat Vector and Bcl-2overexpressing cells whereas less Bak precipitated in Jurkat Bcl-xL cells (IP at the bottom). Bak clearly co-precipitated with Mcl-1 and Bcl-xL in all cell lines. A co-precipitation of Bak with Bcl-2 could be detected only in Bcl-2-overexpressing cells. (B) Bak was precipitated in presence of the harsher detergent Triton X-100 in healthy Jurkat Vector, Jurkat Bcl-2, and Jurkat Bcl-xL cells. 1\% Triton X-100 (upper panel) as well as $0.2 \%$ Triton X-100 (lower panel) abrogated the interaction between Bak and Bcl-2 in Bcl-2-overexpressing cells whereas Mcl-1 and Bcl-xL still co-precipitated with Bak in all tree cell lines indicating a tight interaction of Bak with Mcl-1 and Bcl-xL but not with Bcl-2.

Figure S1: Apoptosis induction and $\Delta \Psi \mathrm{m}$ dissipation in response to Celecoxib. Jurkat Vector, Jurkat Bcl-2, and Jurkat Bcl-xL cells were treated with 50-100 $\mu \mathrm{M}$ Celecoxib for $6 \mathrm{~h}$. The data obtained from flow cytometric analysis was fitted according to the equations described in the "Material and methods" section. (A) shows fitted curves for healthy, AnnV/PI double negative cells (AnnV-/PI-), (B) shows fitted curves for cells with dissipated membrane potential (low $\Delta \Psi \mathrm{m}$ ). The curves for Jurkat Vector and Jurkat Bcl-2 cells were close to each other showing a relatively high sensitivity to Celecoxib, whereas the flat curve for Jurkat Bcl-xL cells shows is much higher resistance to Celecoxib-induced apoptosis and $\Delta \Psi$ m dissipation.

Figure S2: Silencing of Bim and Puma inhibits apoptosis induction after serum withdrawal. Jurkat E6.1 cells were electroporated with $0.25 \mu \mathrm{M}$ bim siRNA, $1 \mu \mathrm{M}$ puma siRNA, simultaneously with $0.25 \mu \mathrm{M}$ bim and $1 \mu \mathrm{M}$ puma siRNA, or with $1.25 \mu \mathrm{M}$ non- 
targeting control siRNA. $24 \mathrm{~h}$ after transfection the serum-containing media were replaced by serum-free media. $72 \mathrm{~h}$ after serum withdrawal, flow cytometric analysis was performed.

Silencing of Bim and Puma protected Jurkat cells from apoptosis (A) and dissipation of the mitochondrial membrane potential (B) after serum withdrawal. 
A

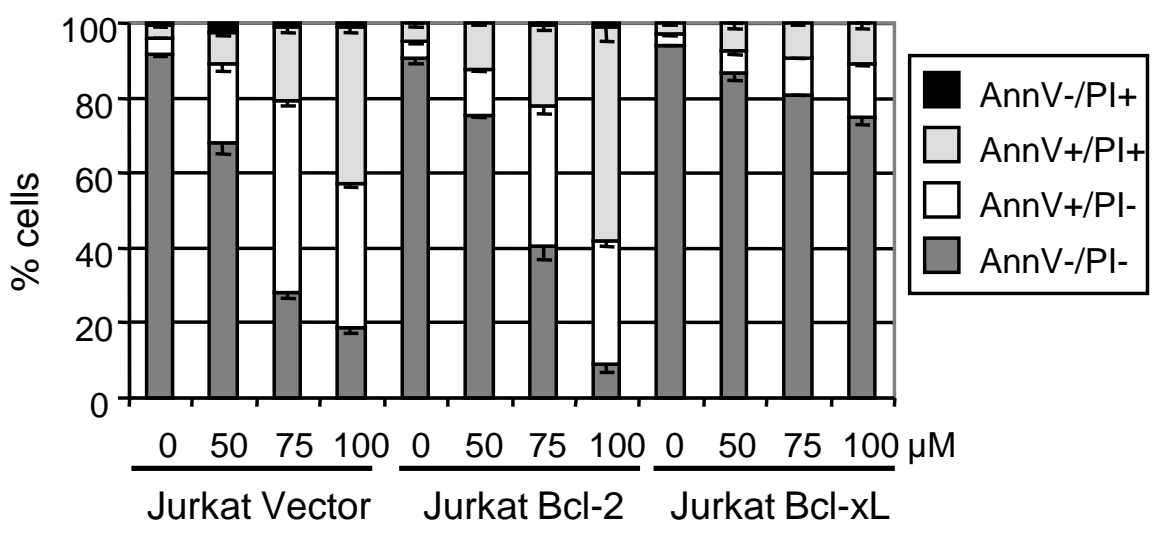

B

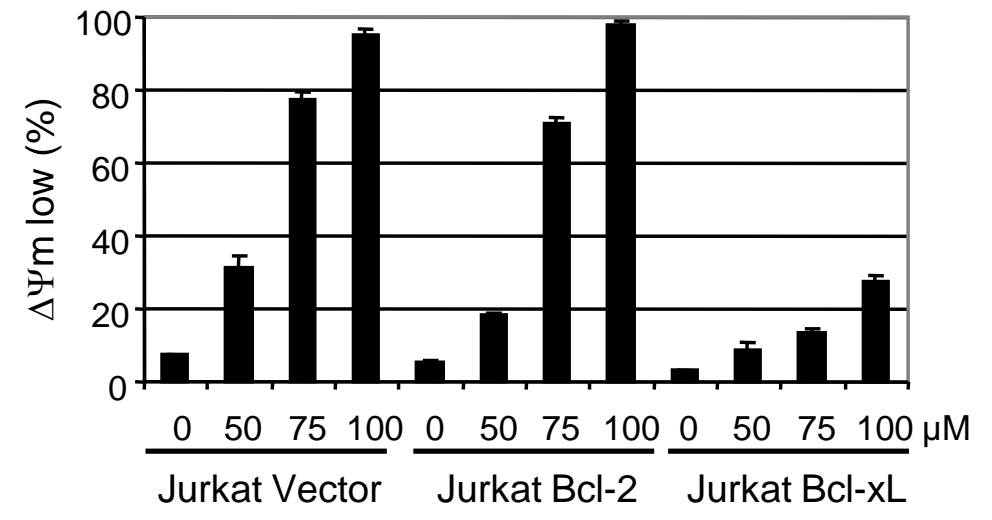

C

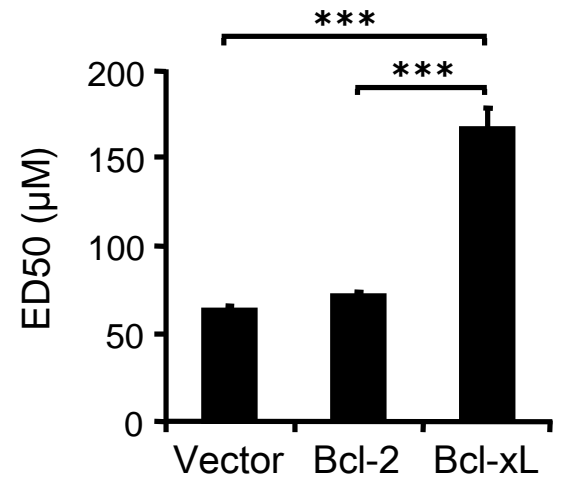

Cells with low $\Delta \Psi \mathrm{m}$

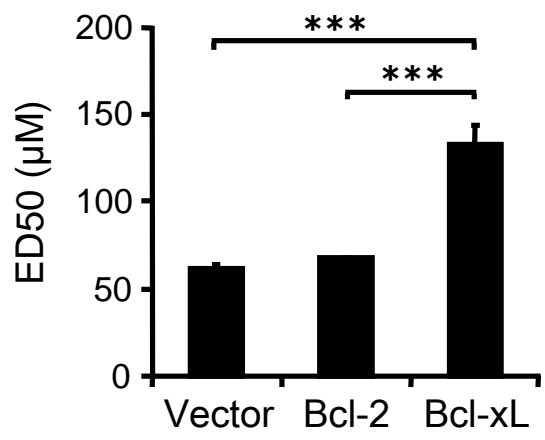

D

\begin{tabular}{|c|c|}
\hline $\begin{array}{l}\text { Jurkat } \\
\text { Vector }\end{array}$ & $\begin{array}{c}\text { Jurkat } \\
\text { BCl-2 }\end{array}$ \\
\hline
\end{tabular}

C9

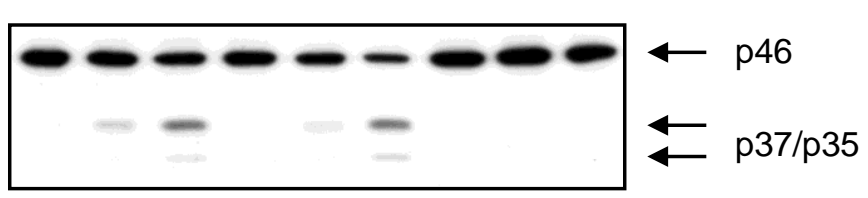

C3

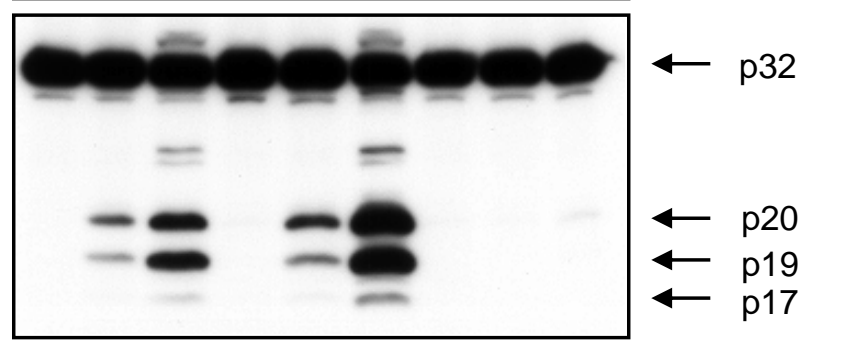

PARP

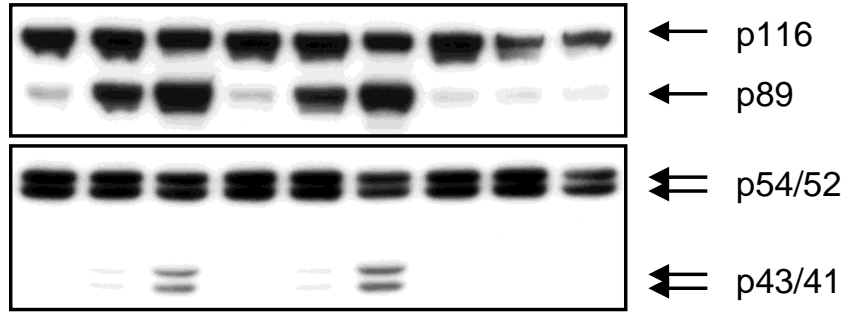

Mcl-1

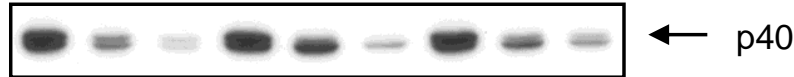

$\mathrm{Bcl}-2$

$\mathrm{Bcl}-\mathrm{xL}$

$---\mathbf{B}--\cdots \leftarrow$ p26

Bak

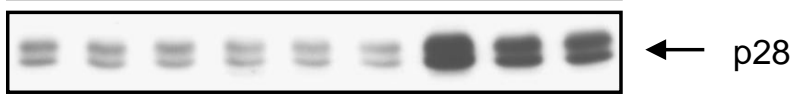

Tubulin 
Figure 2

A

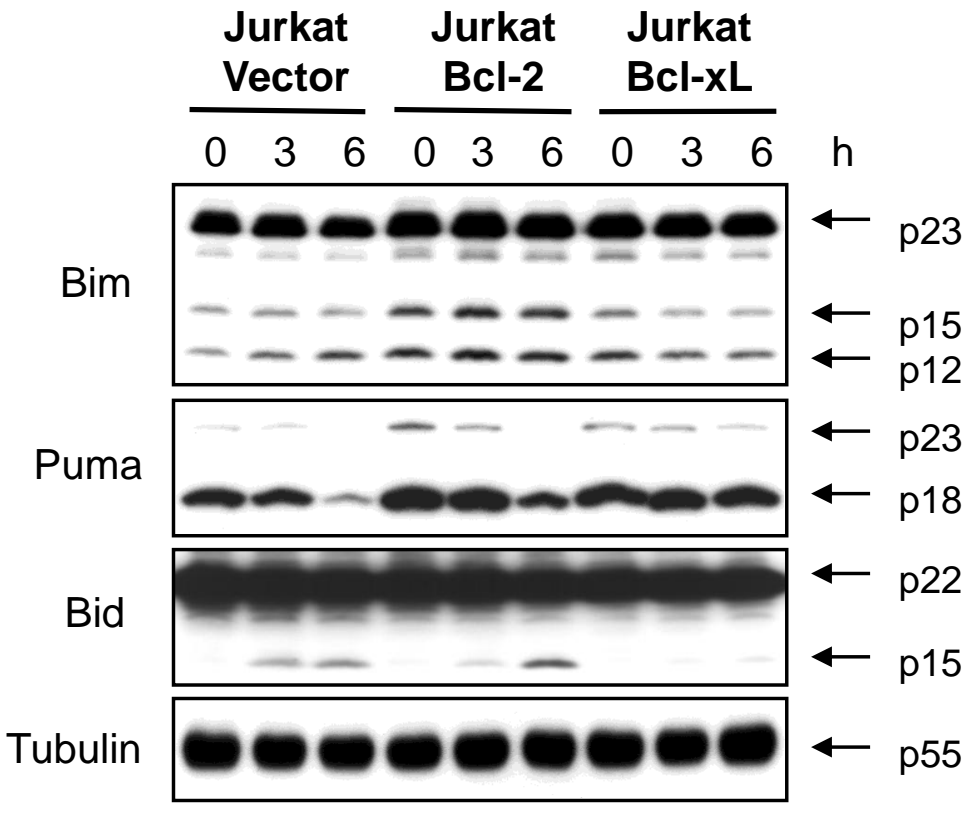

B

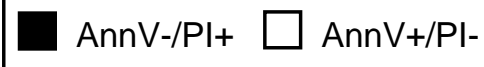

$\square$ AnnV+/PI+ $\square$ AnnV-/PI-
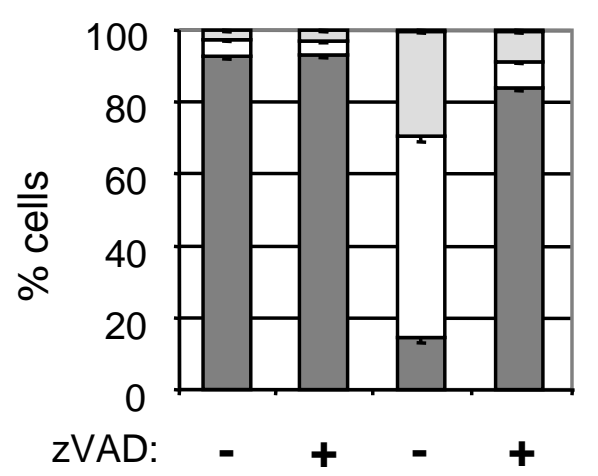
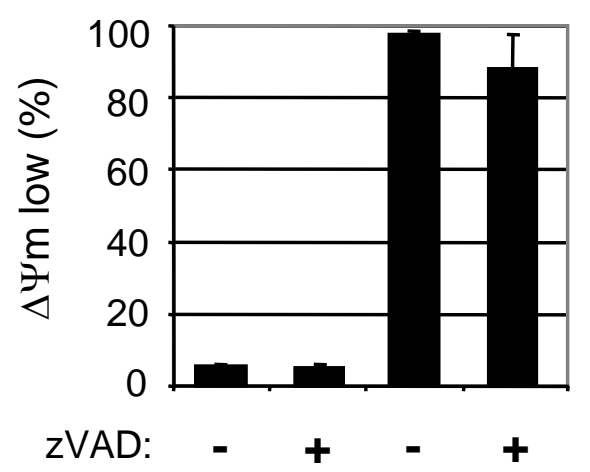

$\begin{array}{ccccc}\text { Celecoxib: } & - & \mathbf{4} & \mathbf{+} & \mathbf{+} \\ & & & +\end{array}$
C

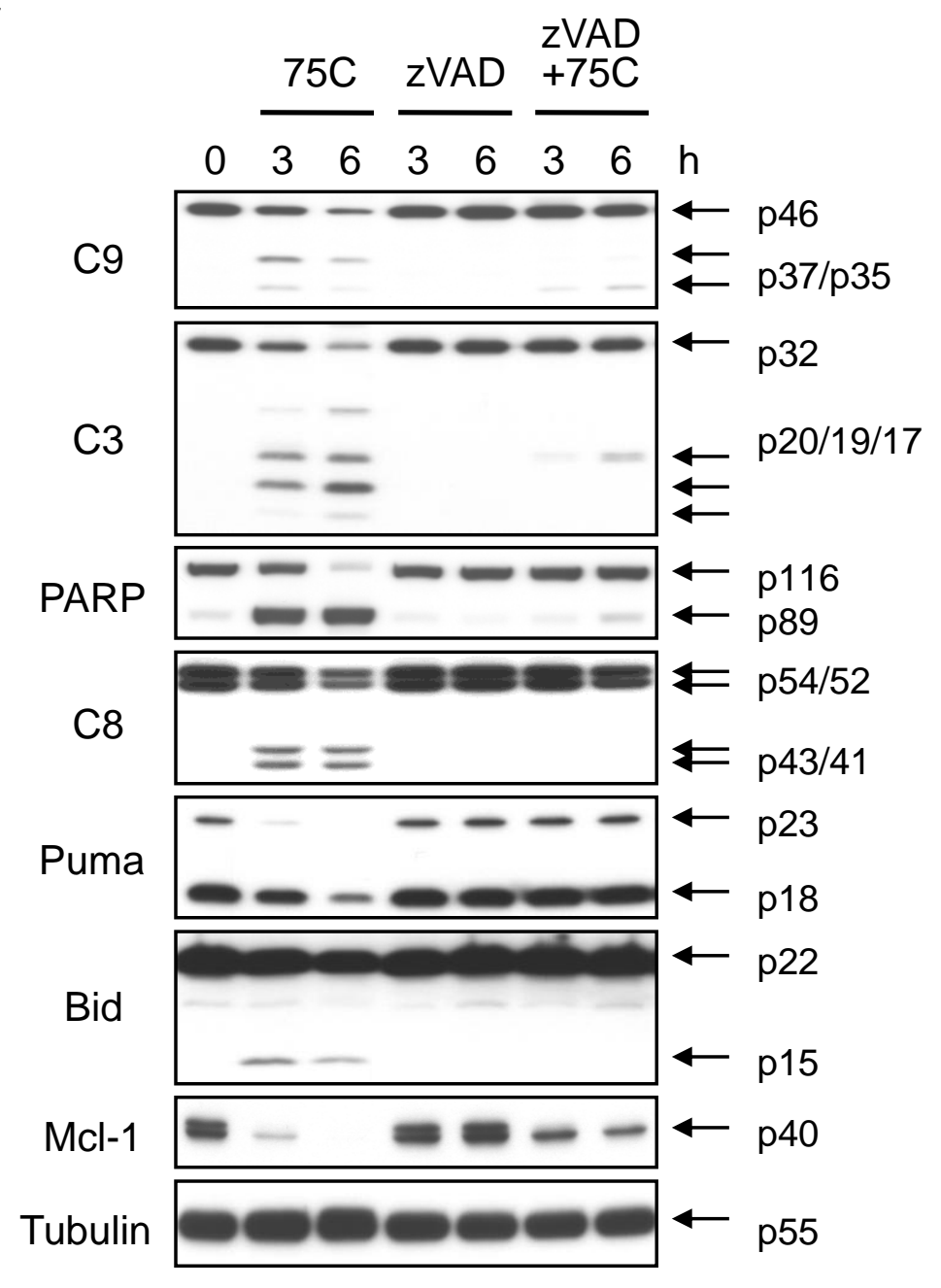


A

$\begin{array}{lllll}0 & 0.5 & 1 & 2 & \mu M \\ M & \text { siRNA }\end{array}$

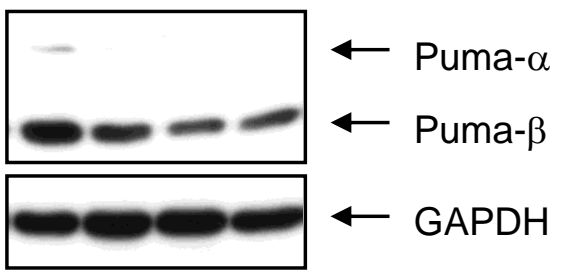

Puma- $\alpha$

Puma- $\beta$

$\begin{array}{llll}100 & 27 & 10 & 13\end{array}$

$\begin{array}{llll}100 & 72 & 47 & 54\end{array}$

B
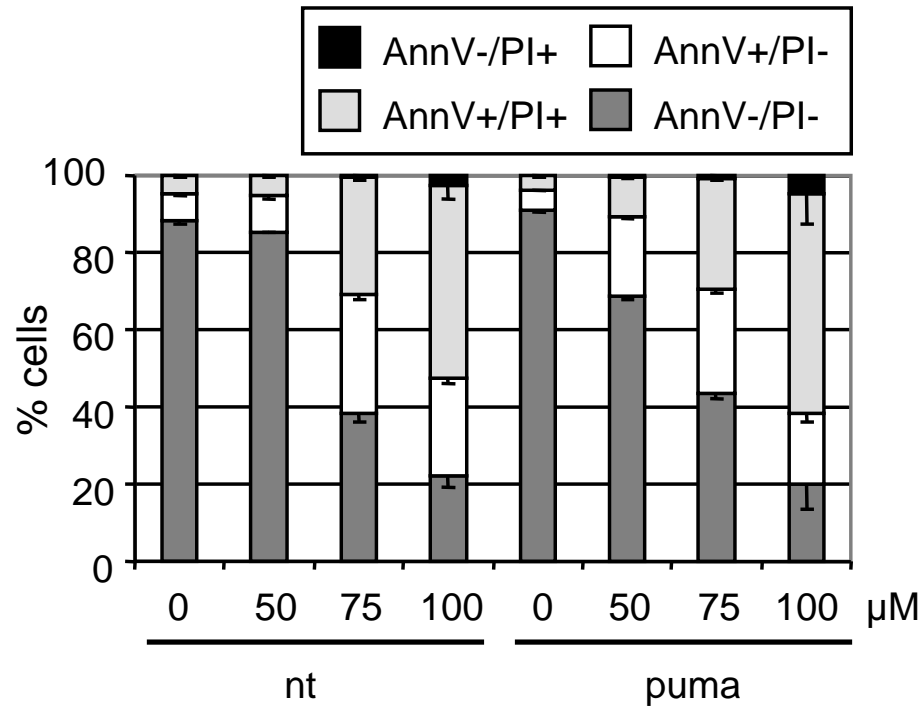

C

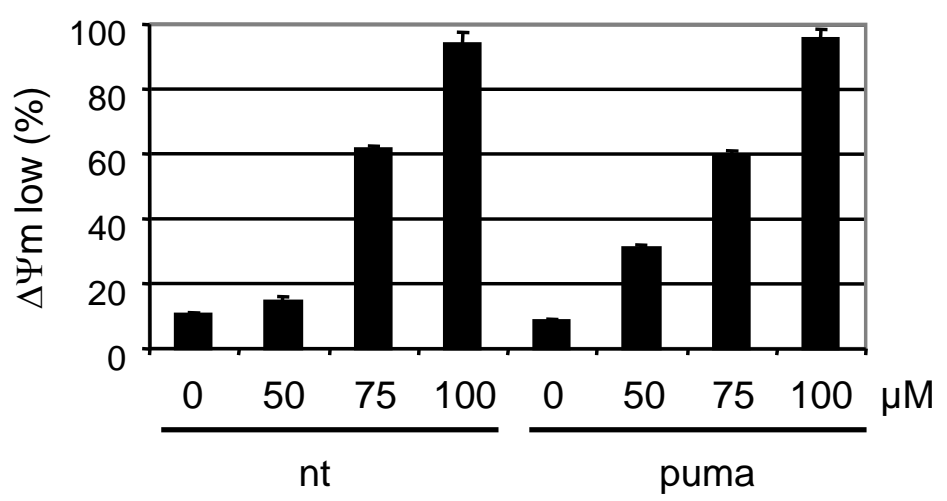

D

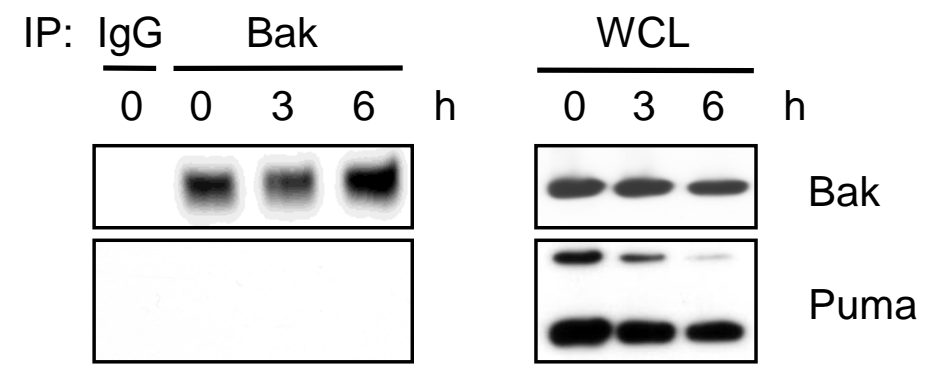

Figure 3
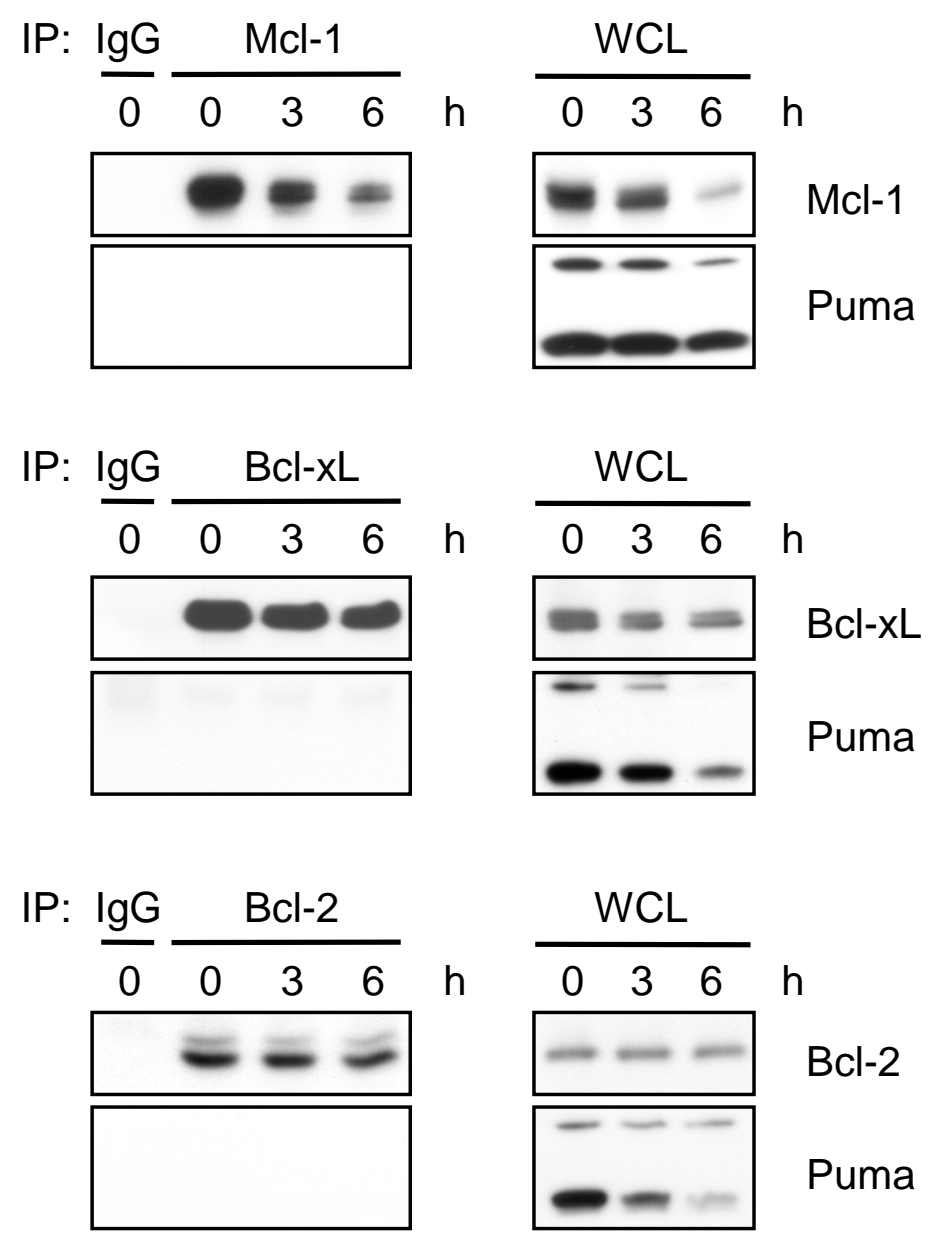
A

IP: $\frac{\lg G}{0} \frac{\mathrm{Bim}}{036} \mathrm{~h}$

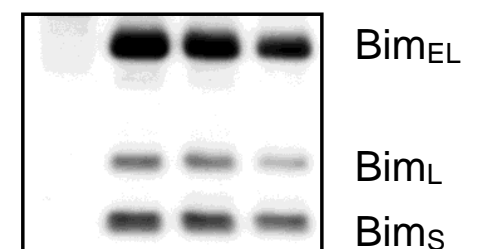

IP: $\frac{\lg G}{0} \frac{\mathrm{Bcl}-2}{0} 3 \frac{3}{6}$ \begin{tabular}{|c|}
\hline$\infty-\infty$ \\
$-\infty-\infty$ \\
$--\infty$
\end{tabular}

$\mathrm{h}$

$\mathrm{Bcl}-2$

BimeL

BimL

Bims

IP: $\frac{\lg G}{0} \frac{\mathrm{Bcl}-\mathrm{xL}}{0} 3$

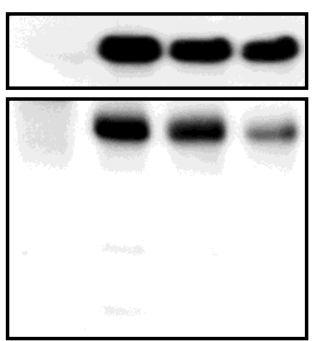

$h$
$B c l-x L$
$B_{E L}$
$B i m_{L}$
$B i m S$

Bcl-2

Bcl-xL
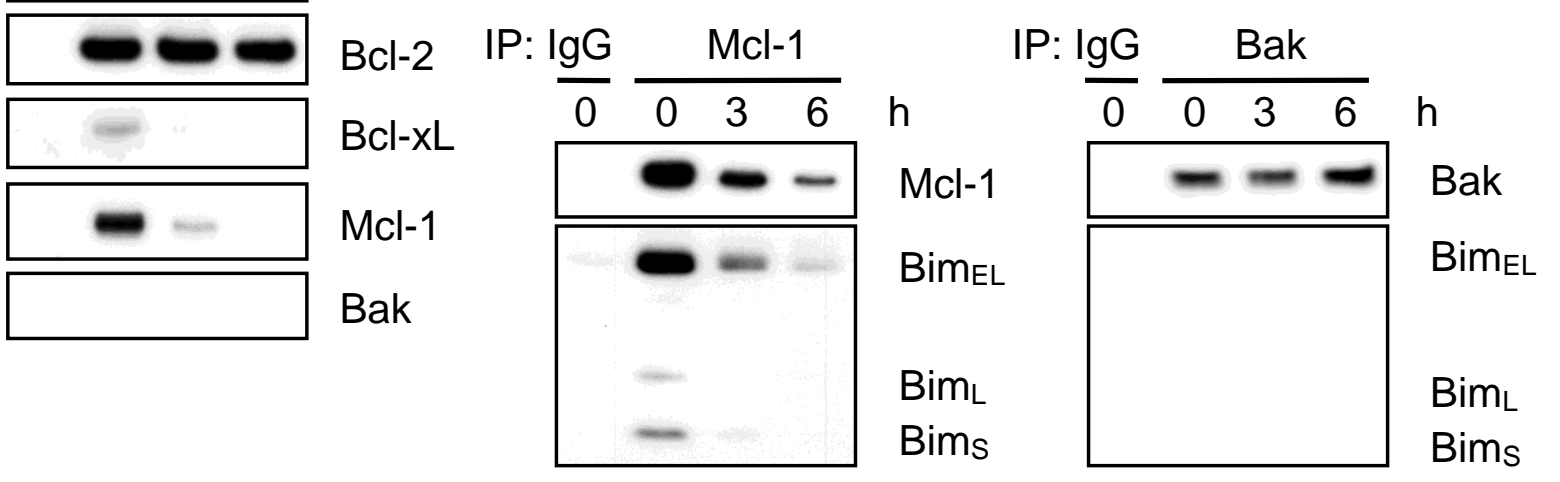

B

Figure 4

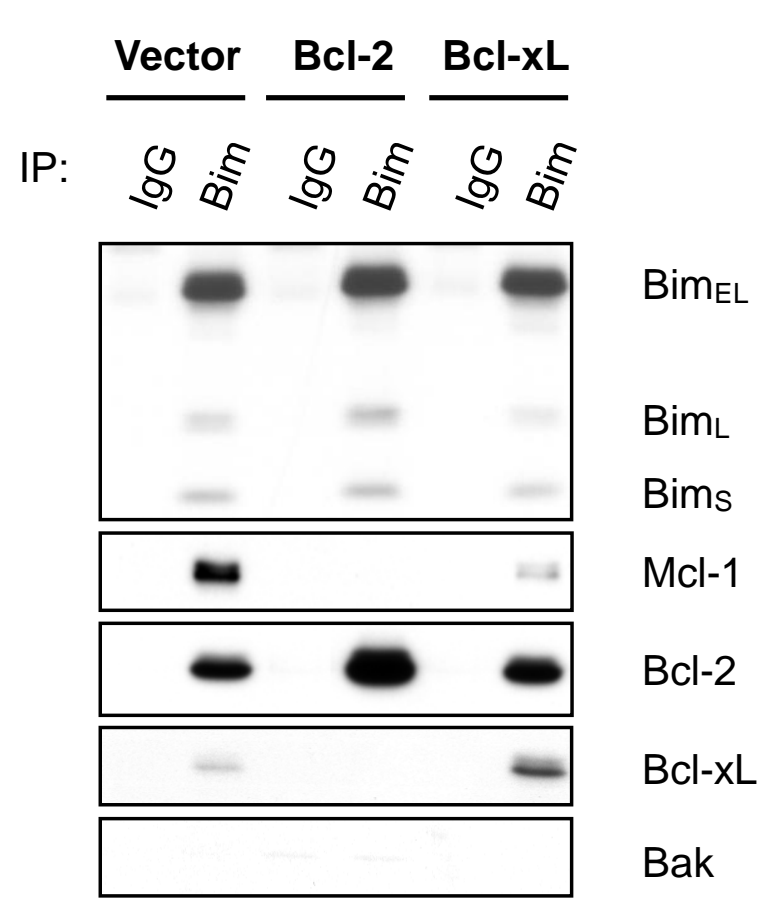

C

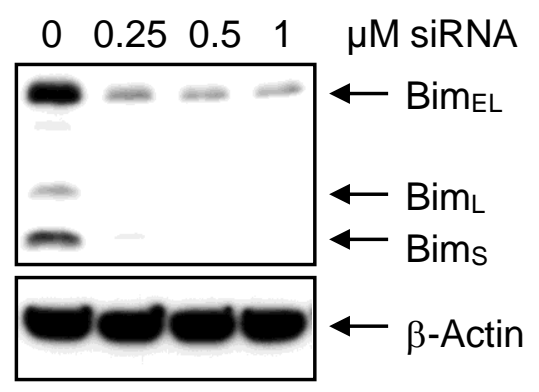

$\begin{array}{lllll}\text { BimeL }_{\text {EL }} & 100 & 25 & 18 & 15\end{array}$

$\begin{array}{lllll}B i m & 100 & 0 & 0 & 0\end{array}$

$\begin{array}{lllll}\text { Bims } & 100 & 5 & 1 & 0\end{array}$

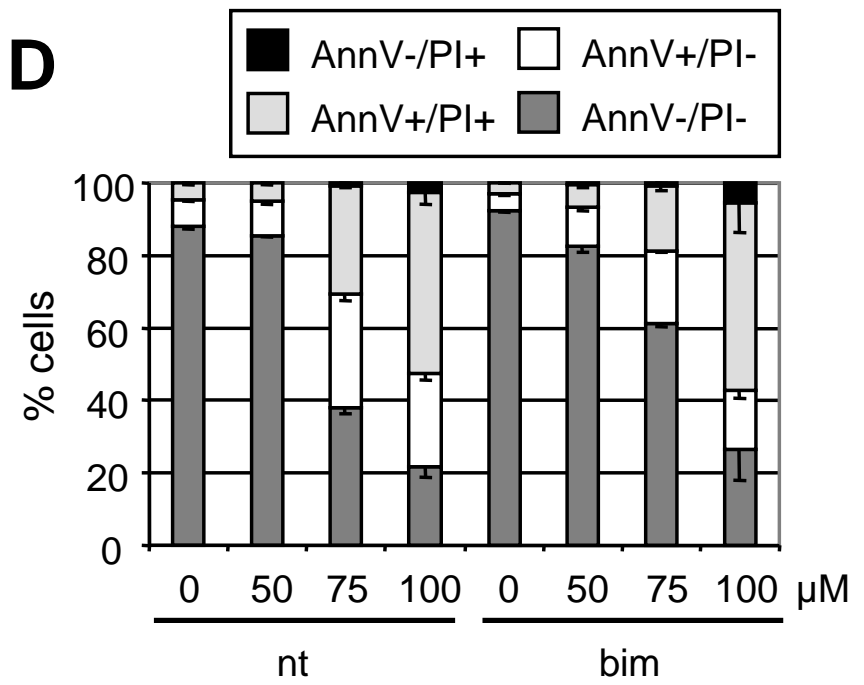

E

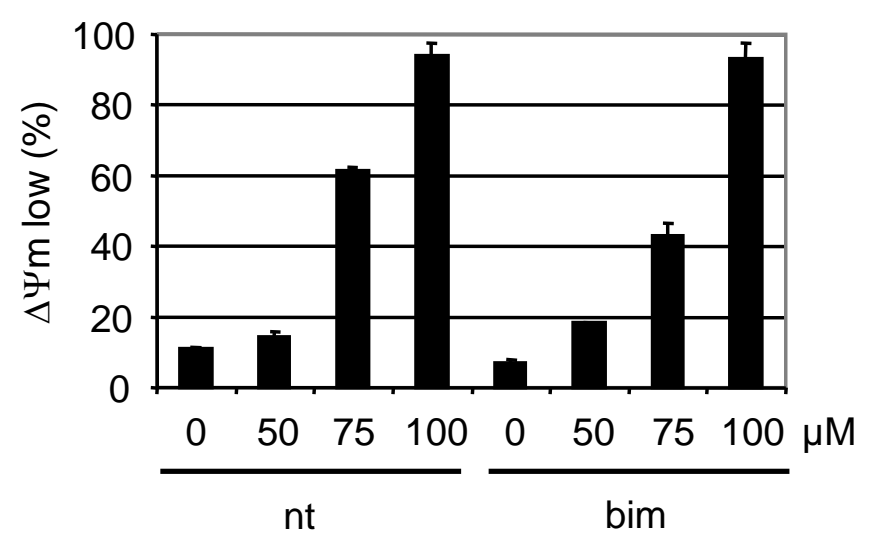


Figure 5

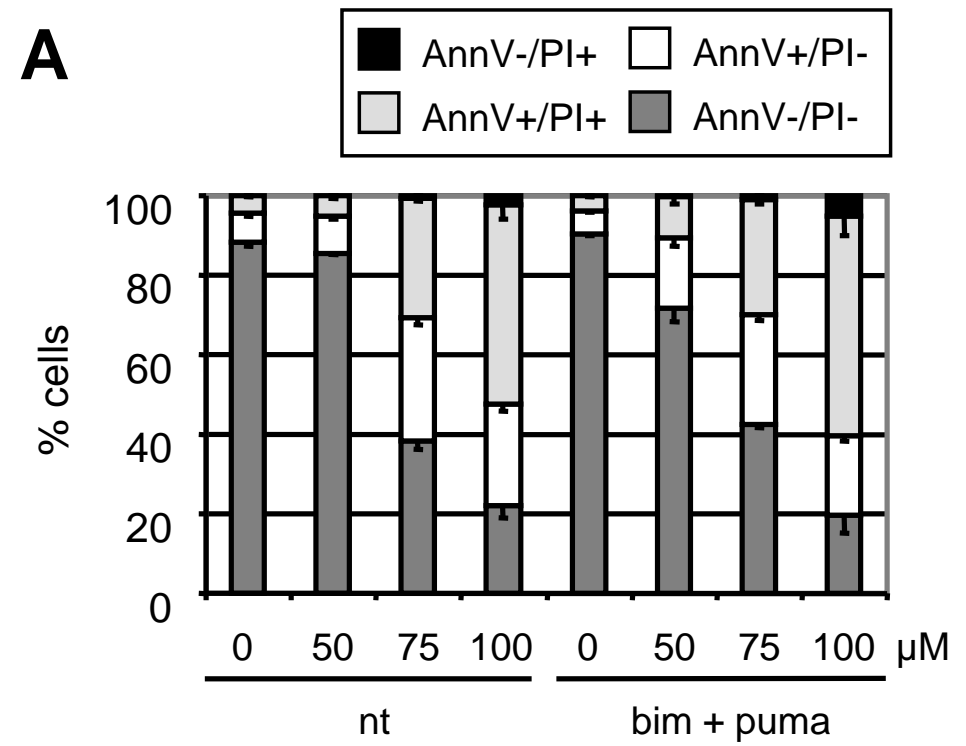

B

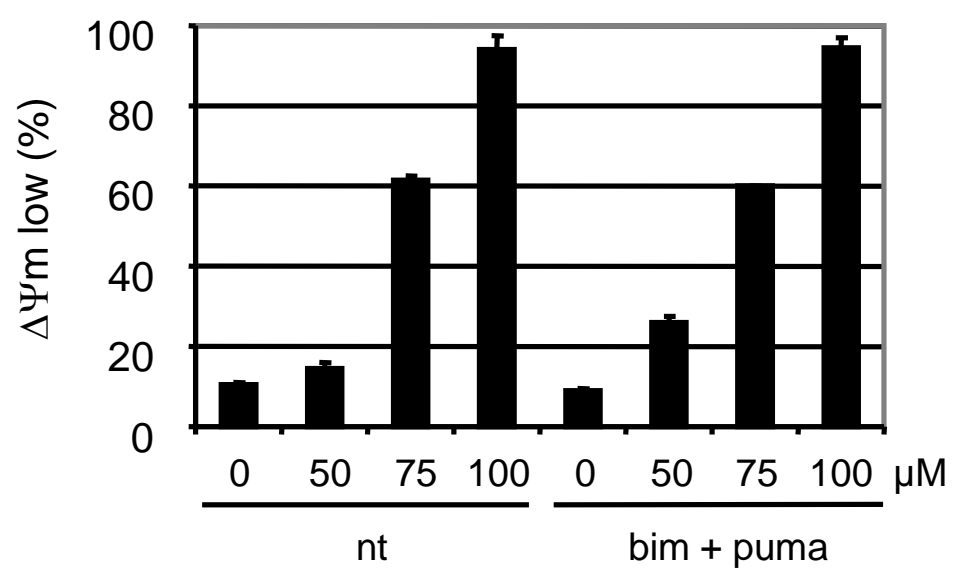


A

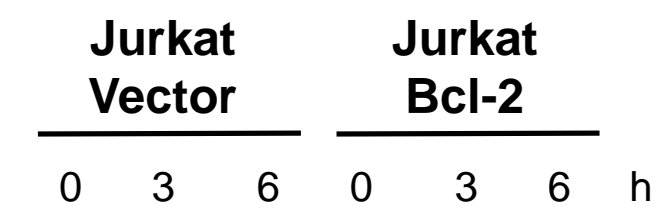

Nur77/TR3

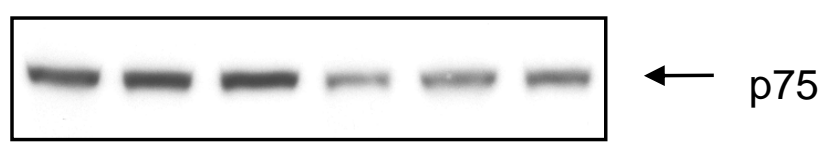

GAPDH

$\longleftarrow$ p37

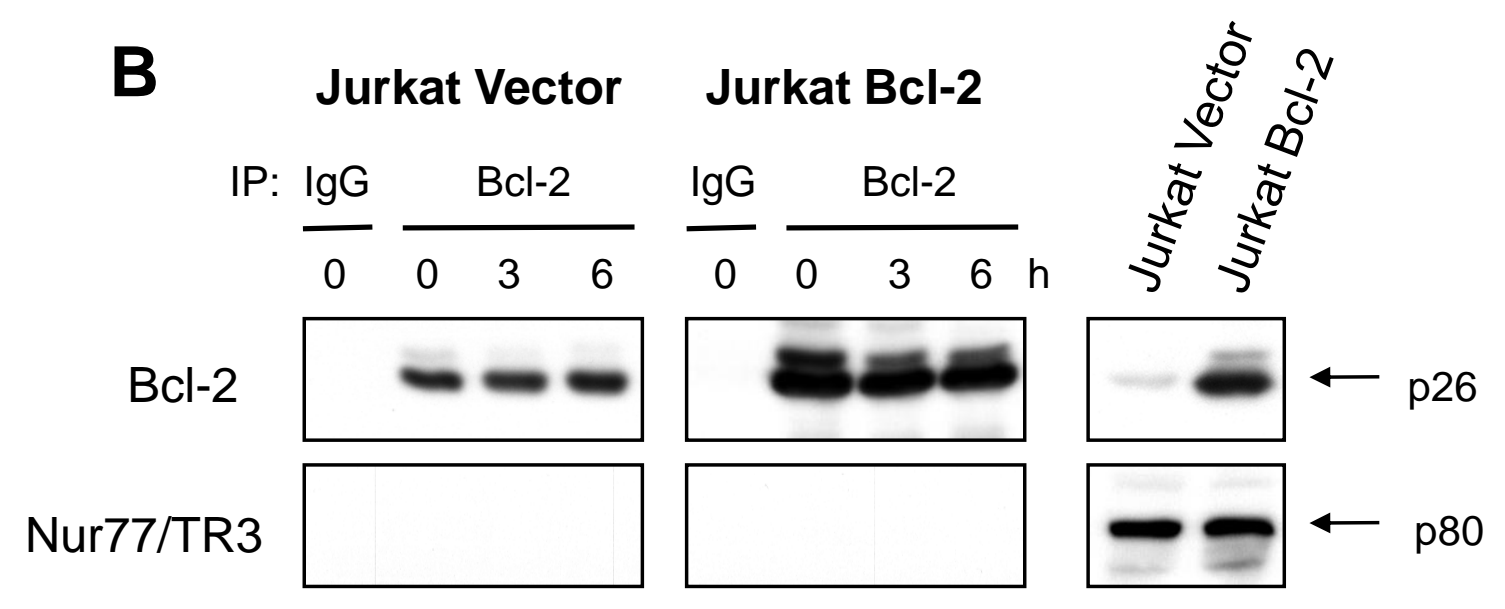


A Jurkat Vector Jurkat Bcl-2 Jurkat Bcl-xL

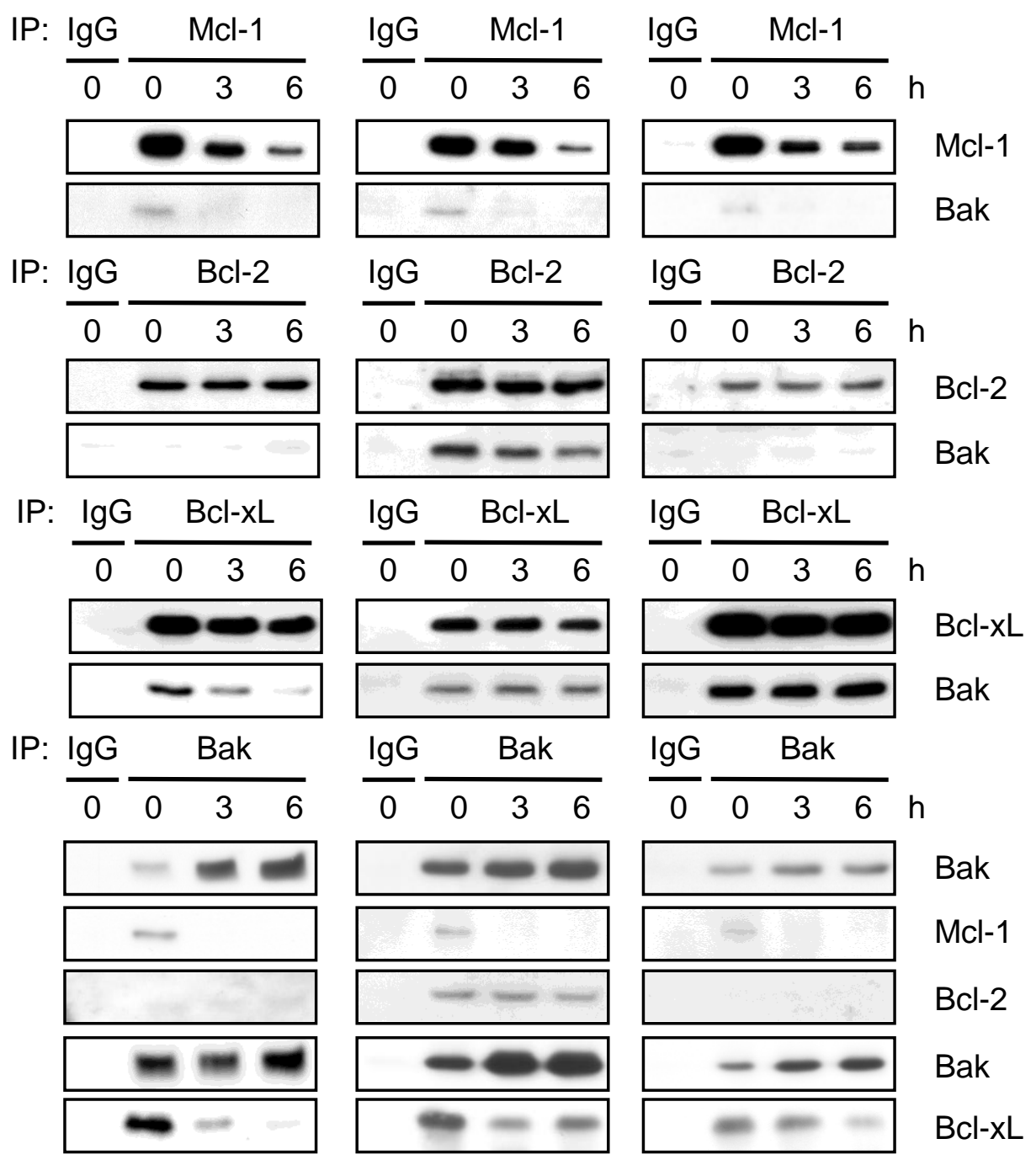

B $1 \%$ Triton X-100

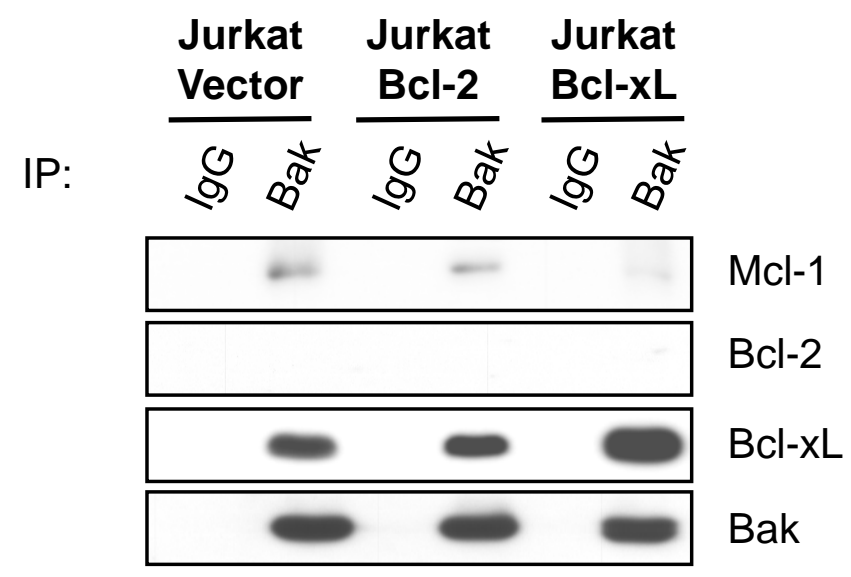

\section{$0.2 \%$ Triton $\mathrm{X}-100$}

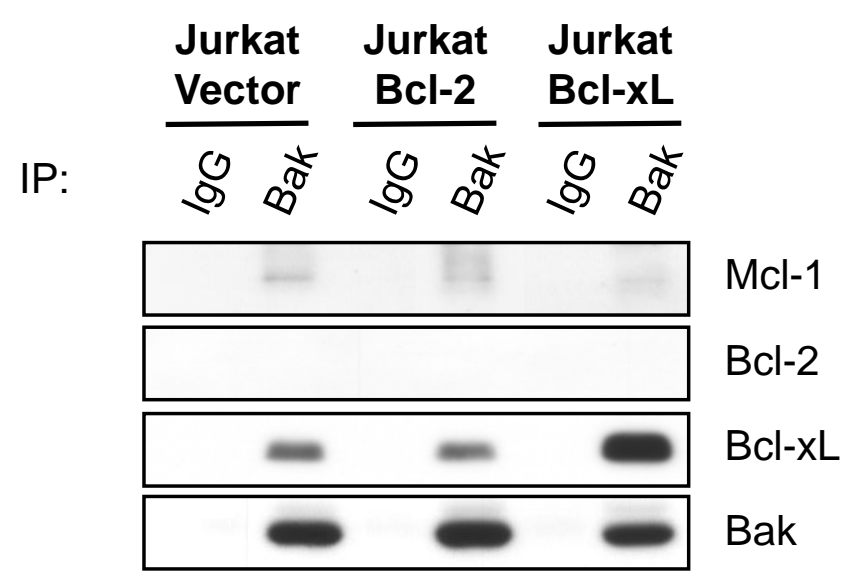


${ }^{\star}$ Graphical Abstract

Jurkat

no overexpression

Jurkat

$\mathrm{BCl}-2$ overexpression

Jurkat

$B C l-x L$ overexpression
Celecoxib

$\rightarrow$ apoptosis

Celecoxib

$\infty$

$\rightarrow$ apoptosis

Celecoxib

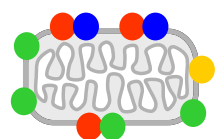

survival
Bcl-2
Bcl-xL
- Mcl-1
Bak
Mcl-1
degradation
Bak
activation

